\title{
Corporate Governance and the Quality of Audit Process: An Exploratory Analysis Considering Internal Audit, Audit Committee and Board of Directors
}

\author{
Nashat Ali Almasria
}

\section{ABSTRACT}

This research aims to offer a better understanding concerning the relationships between Internal Corporate Governance Mechanisms and quality of the external audit process and what are the governance mechanisms that can influence some aspects of the quality of the external audit process. Semi-structured interviews were employed in order to get detail views of the external auditors to explain and clarify how the Internal Corporate Governance Mechanisms can influence the quality of the external audit process as well as offer a better understanding of the relationships between the governance mechanisms and the quality of the external audit process. Adopting this research design (exploratory) was mainly as a response to the recent calls as there is a lack of this kind of study that investigate the relationship between the Internal Corporate Governance Mechanisms can influence the quality of the external audit process. This research focuses on the perception/insight of the Jordanian external auditors regarding the influence of Internal Corporate Governance Mechanisms on quality of the external audit process. Thus, this study uses a sample of 206 Jordanian external auditors for the survey and 13 participants from this sample for the interview. The qualitative study employed the thematic analysis to analyse the interview data. The interview results highlighted that there are different ways and stages that the ICGMs can influence the EAQ, for example, through holding effective regular meeting, ensuring the auditor compliance with the audit requirements "regular monitoring", discussing the initial and significant audit results "draft of discussion", taking necessary follow-up actions "feedback" as well as requesting the auditor to conduct additional tests which can in turn enhance the EAQ. The results also suggest that ICGM can assist improving different aspects of EAQ such as the quality of the evidence that are collected by the ICGM and the valuable guidance from the ICGM to the external auditor. The communication between the ICGM and external auditor can be focused on different issues related to the audit process such as auditors' findings, the effectiveness of internal control, scope limitations and material misstatements which allow improving the effectiveness of audit process. This indicates that, the auditor must be aware of the dynamic deciding of the role of particular mechanisms in improving the external audit process. The results have implications for the practitioners and regulators who are assessing the role of ICGM in improving the reliability of the financial report and auditor's report. The empirical findings demonstrate that different ICGM can influence different aspects of the EAQ. More importantly, the results reveal that audit practice in Jordan is experiencing some difficulties in terms of the independence of the auditor especially, for the small local firms and providing non-audit service. In addition, there is no professional body for board of director; internal audit and audit committee like Jordanian association of certified public accountant (JACPA) for the external auditor, thus, responsibilities of these mechanisms need to be formally overseen by a higher authority. For the policymakers, this study offers a unique proposition to improve the effectiveness of the ICGM to achieve EAQ. These empirical findings of this study also highlight the importance of improving EAQ as a solution for the agency problems through reducing information asymmetry, improving the disclosure practice, level of confidence and assurance of the financial reporting as well as deterring the opportunistic behaviour from different parties. This research extended the existing empirical evidence that investigated the role of the internal governance mechanisms in the audit process.

Keywords: Audit Committee and Board of Directors, Internal Audit.
Submitted: October 30,2021

Published: January 22, 2022

ISSN: $2507-1076$

DOI: $10.24018 /$ ejbmr.2022.7.1.1210

Nashat Ali Almasria*

Ph.D., Assistant Professor, Faculty of Business, Department of Accounting, Philadelphia University, Jordan.

(e-mail: nalmasria ${ }^{\circledR}$ philadelphia.edu.jo)

*Corresponding Author 


\section{INTRODUCTION}

Corporate governance mechanisms and audit quality play a vital role as effective monitoring tools (Ismail et al., 2016). Thereby, internal audit, board of director and external audit are considered main monitoring and controlling tools to ensure the reliability of the corporate governance structure and prevent fraud. Improving audit quality and corporate governance mechanisms is considered an important issue for companies around the world, including Jordan. Furthermore, recently the literatures on ICGM and EAQ have been prolific. This section reviews the existing literature in two main areas; EAQ and ICGM which includes board of directors, audit committee and internal audit factors as such this would address the relevant literature gaps as highlighted in the literature gap (see section 1.6). Previous studies have attempted to establish an empirical relationship between ICGMs and EAQ. Reviewing literature on the relationship between ICGM and EAQ shows that recent studies have examined the relationship between on ICGMs and EAQ. These studies on ICGM and EAQ have focused on the relationship between some characteristics of board of directors, and EAQ (Kane and Velury, 2004; Zanani et al., 2008; Voeller et al., 2013; Kikhia, 2014). Moreover, many publications on the relationship between ICGMs and EAQ specifically focus on ownership structure, audit committee and EAQ. However, there are still some gaps in ICGMs such as external and internal audit which can be addressed in order to enhance investor confidence. Moreover, in wake of agency problem, many scandals and collapses have happened in large companies around the world, including Jordan (O'Sullivan, 2000; Soliman and Elsalam, 2013). The main reasons and allegations for scandals are weakness of corporate governance, mismanagement of business, misappropriation of corporate assets, audit failure and fraud (Adeyemi et al., 2012). The literature examines the association between ICGM and EAQ which started after the financial crisis happened in these companies. The literature review is structured and developed in order to review and discuss the relevant studies on the relationship between ICGMs and EAQ. Prior literature reviews on corporate governance and audit have examined the impact of ICGMs on EAQ. However, this research differs from these prior studies; the current study focuses on internal audit and boards of directors and takes various EAQ indicators (audit fees and audit firm size). Additionally, this study examines the opinion of the external auditors concerning the influence of internal audit on EAQ. In order to arrange and engage this review of literature, this study adopts the point of view that corporate governance structure comprises four cornerstones: board of directors, external audit, audit committee and internal audit. This point view guides the review of the empirical literature and hypotheses development. The board of directors and audit are the main mechanisms that guarantee accountability and credibility in the financial reporting system (Zanani et al., 2008). These are the main mechanisms recommended for diminishing agency problems and conflicts of interest (Florackis, 2008). According to the literature previous empirical findings till date are not conclusive and comprehensive to address all corporate governance mechanisms; thus, this study investigates and addresses these mechanisms. In Jordan, recent literature has focused on the relationship between the ICGMs and EAQ. Most of these studies focus on the determinants of audit quality, with only a few articles on finding the relationship between audit quality and corporate governance mechanisms in Jordan. The relationship between ICGMs and EAQ has not been researched extensively and comprehensively in the context of Jordan. Based on the research to date, only Zureigat's (2011) study examined the influence of corporate governance represents by ownership structure, on audit quality. The findings highlighted that there is a positive and significant association between audit quality and institutional ownership, and Hassan's (2014) research aimed "to investigate the impact of composition of board of director and structure of audit committee on audit quality (audit fees) in Jordan listed companies". Hassan (2014) found a significant relationship existed between institutional ownership and EAQ. Moreover, O'Sullivan, (2000) revealed that a significant association exists between ownership concentration and EAQ in the UK context. The board of directors is considered a crucial monitoring mechanism on management activities (Lin and Liu, 2009; Bettinelli, 2011). This is because the board of directors aims to protect investments made by the investors from the abuse of management (Bathala and Rao, 1995). Moreover, through the activities that internal auditors carry out, internal auditors increase the validity and fairness of financial information, improve the behaviors of employees who are working at these companies and reduce the risks of managerial and financial corruption (Felix Jr and Gramling, 2001).

\section{DESCRIPTION AND SIGNIFICANCE OF THE CORPORATE GOVERNANCE MECHANISMS}

Several endeavours have been made to define and interpret corporate governance, its scope, relevant theories, and other concerns relating to the subject of corporate governance (Cadbury report, 1992; Turnbull, 1997; OECD, 2004). There are many definitions discussed in the previous studies and many authors and regulators have tried to define corporate governance, but each one has a different view of the world, so the term of corporate governance can be explained and defined differently based on the context. Furthermore, the corporate governance is the system in which businesses are monitored of ensuring corporate accountability and responsibility for different constituencies in the companies (Donaldson, 1990). Moreover, Tricker, (1994, p. 30) describes corporate governance as system in which explains and coordinates the relationship between the main players in the company who are owners, management, audit committee, boards of directors and external auditor. Specifically, the main pillar of corporate governance is accountability. There are different governance techniques which are used to balance the needs of different parties. Shleifer and Vishny (1997) vision corporate governance as a set of techniques which are employed by owners in order to guarantee themselves of receiving a yield on their asset. According to the previous governance studies and agency theory, governance system includes internal mechanisms (i.e., internal audit and board of directors) and external mechanisms (i.e., external audit); each 
mechanism has a different task (Makni et al., 2012). The EAQ is a viable external mechanism to improve the quality of the corporate governance structure in the business besides the internal mechanism of corporate governance (Zanani et al., 2008). This is because the external and internal mechanisms are considered the main mechanisms of monitoring process in the financial reporting system Beisland et al., 2015. This supported by Beisland et al. (2015) who highlight that auditing is key part of the governance system. According to the previous studies there are various ways and opportunities for the interactions and cooperation between external auditor and other internal 71 governance bodies, since all these bodies work together to improve the control system and financial report quality (Zanani et al., 2008; Adeyemi et al., 2012; Karaibrahimoglu, 2013). The board of director is considered a crucial internal monitoring mechanism over management activities (Lin and Liu, 2009; Bettinelli, 2011), this is because it aims to protect investments of the investors from the abuse of management (Bathala and Rao, 1995). Moreover, through the activities of internal auditors that carry out, internal auditors increase the validity and fairness of financial information, improve the behaviours of employees who are working at these companies and reduce the risks of managerial and financial corruption (Felix Jr and Gramling, 2001). The external auditors are considered to be independent party of the influence of the internal mechanisms of corporate governance (Antle, 1984). However, they perform their duties in helping from different internal bodies (Fan and Wong, 2005). According to agency theory, independent audit is an important monitoring and checking mechanism (Jensen and Meckling, 1976). This is supported by other authors like Holm and Laursen (2007) who consider the external auditor necessary to evaluate and confirm the financial reporting of firms. Furthermore, effective board of director with high quality of audit service can be largely reduced the fraud and corruption (Abdulnafea et al., 2021). Moreover, if the board members perform their duties properly and effectively this will prevent audit failures, mismanagement actions and conniving between internal bodies and external auditors (Zahra and Pearce, 1989; O'sullivan, 2000; Zanani et al., 2008). Furthermore, each party perform and function independently with collaboration with each other's, so the efficiency of external audit service is affected by the weakness or the strength of the internal corporate mechanisms (Alawaqleh and Almasria, 2021), hence, the weakness of internal corporate mechanisms has influence of the effectiveness of external audit service (Ball et al., 2000). The main aim for the interaction between these governance parties is to ensure accountability of the managers, board of directors and external auditors. Accountability is one of the most significant accounting dimensions of corporate governance system in the company (Almasria, 2018). According to this definition, the providers of funding use ICGMs in order to guarantee their rights and they are able to earn revenue from their enterprise. From the Jordanian regulatory authority's point of view, corporate governance is a set of mechanisms, guidelines and regulations that monitor the relationships between different parties in companies, such as boards of directors' managers, suppliers, auditors, and other stakeholders as well as distribution of rights and accountabilities among these various parties
(Alawaqleh and Almasria, 2021). Therefore, corporate governance indicates a set of relationships, procedures, standards, and rules that affect the direction and control of a company by using various mechanisms (Tricker, 1994). This description concentrated on the purpose of corporate governance which organizes and coordinates the relationship between the key bodies in the company who are shareholders, management, boards of directors, external auditor and audit committee. The main aim for the interaction between these parties is to allow accountability of each other. Specifically, the main pillar for corporate governance is accountability; each party is accountable to another party and each party should have contact with the others regularly and effectively (Almasria, et al., 2021).

\section{THE DESCRIPTION OF EXTERNAL AUDIT QUALITY}

There is a considerable debate about the common description of EAQ as well as the lack of worldwide recognition and acceptance of a description for EAQ. As supposed by the Financial Reporting Council FRC: "There is no single agreed definition of audit quality that can be used as standard against which actual performance can be assessed" (FRC, 2000:16). The definition of audit quality means different things with a distinctive perspective and different people, each party may view audit quality in a distinctive manner. In other words, there is the probable perception of audit quality through the lens of investors, but the audit committee members have a different observation (IAASB, 2011). In addition, there are various definitions of the quality of audit services. Deangelo (1981: p. 186) described the quality of audit services and his illustration considers the most widespread description for EAQ which is "the market evaluated joint probability that a given auditor will both (a) detect a breach in the client's accounting system, and (b) report the breach". This implies that the EAQ takes into account two basic issues discovering and reporting. In other words, EAQ would be measured by capturing and reporting the material misstatement and any weakness in the financial reporting system for stakeholders. Deangelo (1989) suggested that the key roles for external auditors are oversight and supervision of the corporate governance system. Moreover, according to Gronroos (1988) quality is measured by achieving client needs and requirements, this quality are represented in achieving shareholders requirements and needs. Moreover, quality of audit is achieved by making sure that all the financial transactions are recorded and disclosed according to the generally acceptable accounting rules and guidelines for example IFRS, and that the published financial reports conform with the data provided in the business's books, and the auditor report testifies that these data fairly represent the outcomes of the company's transactions during a particular period of time as well as the auditors collect adequate and appropriate evidence of auditing (Halbouni, 2015; Fan and Wong, 2005; (Alawaqleh et al., 2021).

The demand for audit service arises from separation between shareholder (principal) and manager (agent), which means that the companies' owners differ from the managers (Almasria, 2018). This led to two important main problems; information asymmetry between the owners and agents, and 
opportunistic behaviour from the managers (Jensen and Meckling, 1976; Arnold and De Lange, 2004). Furthermore, the main tasks for an auditor included the discovery of material misstatements, rectification of such errors and in some cases prevention of any significant omissions, fraud, or misleading financial data (Palmrose, 1988; Halbouni, 2015). In order to better comprehend the quality of audit process, it is helpful to realise the important role played by the auditor as an oversight role. External auditors act as independent monitors of shareholders over managerial actions (Deangelo, 1981). Furthermore, the literature also shows that there are various possible approaches to measuring EAQ. There is still no consensus about the measurement of EAQ; some prior studies considered the dichotomous 'Big-4/ Non-Big-4' as indicators of EAQ (Zanani et al., 2008; Hussainey, 2009; Mahdavi et al., 2011; Zureigat, 2011; Soliman and Elsalam, 2013). Hence, most prior studies measure EAQ by the size of the audit companies because bigger companies hire qualified and skilled staff, they have more resources and better techniques, since most of previous studies suppose Big-4 audit firms which have better EAQ compared to non-top 4 (Lawrence et al., 2011). There are many studies which have investigated the effect of audit fees on EAQ and they found that audit fees are considered an EAQ indicator (Hoitash et al., 2007), this is supported by previous research that have used audit fees as EAQ indicator (O'Sullivan, 2000; Kane and Velury, 2004; Voeller et al., 2013; Kikhia, 2014), thus, the definition should be based on the main aim of the audit which focused on discovering the material misstatements, ensuring the financial transactions and statements present the real condition of the company and report the results of the audit work to the shareholders, in achieving these objective the external audit need to interact with the ICGM.

\section{DATA COLLECTION}

Semi-structured interviews were conducted instead of unstructured interview because it fits more with research design and this stage conducted after quantitative research to get deep understanding of research questions (Creswell, 2003). The list of all the external auditors provided the data about the population of the study. Thereafter, purposive sampling was employed where the respondents were purposively selected due to the participant's knowledge, experience and position (Fylan, 2005; Teddlie and Yu, 2007, Tongco, 2007). The external auditors who are board members in the JACPA were contacted first, the choice to contact them first was due to their position as external auditors and as board member of JACPA so they are experts in this area and they have more knowledge and experience based on their position, this leads the researcher to start contacting them, this improve the credibility of their contribution because they're policy makers as well, after contacting them; four of them accepted to do interview, due to the difficulties to meet the auditor because of the nature of their work, these board members refer the researcher to some of the auditor who fulfil the selection criteria, five interviews were conducted with external auditors who are working in big audit firms, other four interviews were conducted with auditors who are working on local audit firms, the researcher contacted them and sent the notification letter and consent form then identifying the place and time for the interview. Therefore, these external auditors provided rational insight and contribution to the interview questions. The translation was conducted for the interviews' transcripts by expert certified translator, as the interviews were conducted by Arabic language (the participant's primary language), in order to ensure the accuracy of the translation, it was checked by the researcher because the translator is not specialised in the accounting area. The section provided background information about four aspects of the interviews which are the interview duration, participants' position and experience. Table 2 offers an overview of Interview respondents' demographics. It can be observed that the majority of the interviewees have experience more than 5 years, it can be also noted that the interview duration from (31-70) minutes. It can also be seen from the table $31 \%$ of the respondents are board of director of JACPA, most respondents $38 \%$ are auditors in Big four firms and $31 \%$ are working in local firm. The criteria for choosing the participants were explained earlier.

TABLE I: INTERVIEW RESPONDENTS' DEMOGRAPHICS

\begin{tabular}{|c|c|c|c|}
\hline Auditor number & $\begin{array}{l}\text { Interview } \\
\text { Duration }\end{array}$ & Position & Experience \\
\hline $\begin{array}{c}\text { External Auditor } 1 \\
\text { (EA1) }\end{array}$ & 55 Minutes & $\begin{array}{c}\text { Board of director } \\
\text { of JACPA }\end{array}$ & $\begin{array}{c}\text { More than } 10 \\
\text { Years }\end{array}$ \\
\hline $\begin{array}{c}\text { External Auditor } 2 \\
\text { (EA 2) }\end{array}$ & 40 Minutes & $\begin{array}{l}\text { Manger-Local } \\
\text { firm }\end{array}$ & 7 Years \\
\hline $\begin{array}{c}\text { External Auditor } 3 \\
\text { (EA3) }\end{array}$ & 70 Minutes & Partner - Big four & 9 Years \\
\hline $\begin{array}{c}\text { External Auditor } 4 \\
\text { (EA4) }\end{array}$ & 65 Minutes & $\begin{array}{l}\text { Board of director } \\
\text { of JACPA }\end{array}$ & $\begin{array}{c}\text { More than } 10 \\
\text { Years }\end{array}$ \\
\hline $\begin{array}{c}\text { External Auditor } 5 \\
\text { (EA5) }\end{array}$ & 35 Minutes & $\begin{array}{l}\text { Senior auditor- } \\
\text { Big four }\end{array}$ & 3 Years \\
\hline $\begin{array}{c}\text { External Auditor } 6 \\
\text { (EA6) }\end{array}$ & 45 Minutes & $\begin{array}{l}\text { Board of director } \\
\text { of JACPA }\end{array}$ & 7 Years \\
\hline $\begin{array}{c}\text { External Auditor } 7 \\
\text { (EA7) }\end{array}$ & 53 Minutes & $\begin{array}{c}\text { Senior auditor - } \\
\text { Big four }\end{array}$ & 4 Years \\
\hline $\begin{array}{c}\text { External Auditor } 8 \\
\text { (EA 8) }\end{array}$ & 43 Minutes & $\begin{array}{l}\text { Senior auditor - } \\
\text { Local firm }\end{array}$ & 5 Years \\
\hline $\begin{array}{l}\text { External Auditor } 9 \\
\text { (EA 9) }\end{array}$ & 53 Minutes & $\begin{array}{l}\text { Partner - Local } \\
\text { firm }\end{array}$ & 8 Years \\
\hline $\begin{array}{c}\text { External Auditor } 10 \\
\text { (EA 10) }\end{array}$ & 37 Minutes & $\begin{array}{c}\text { Senior auditor - } \\
\text { Big four }\end{array}$ & 3 Years \\
\hline $\begin{array}{l}\text { External Auditor } 11 \\
\text { (EA11) }\end{array}$ & 51 Minutes & $\begin{array}{l}\text { Senior auditor- } \\
\text { Big four }\end{array}$ & 4 Years \\
\hline $\begin{array}{c}\text { External Auditor } 12 \\
\text { (EA12) }\end{array}$ & 33 Minutes & $\begin{array}{c}\text { Board of director } \\
\text { of JACPA }\end{array}$ & $\begin{array}{c}\text { More than } 10 \\
\text { Years }\end{array}$ \\
\hline $\begin{array}{c}\text { External Auditor } 13 \\
\text { (EA13) }\end{array}$ & 31 Minutes & $\begin{array}{c}\text { Partner- - Local } \\
\text { firm }\end{array}$ & $\begin{array}{c}\text { More than } 10 \\
\text { Years }\end{array}$ \\
\hline
\end{tabular}

\section{A. The Quality Criteria of the Qualitative Data}

The quality criteria in qualitative research can be addressed through improving the trustworthiness and accuracy of the qualitative data collection and analysis steps (Franklin and Ballan, 2001; Golafshani, 2003). In qualitative stage in this study, there are various field procedures that the researcher employed them to ensure the accuracy and trustworthiness of the qualitative data and the results of the analysis (Frost, 2011). Structured procedures and systematic approach were followed by the researcher in order to collect and analyse the qualitative data, this allow ensuring the rigorous of the qualitative results (Franklin and Ballan, 2001; Golafshani, 2003). In order to guarantee the application of mixed methods in the accurate and effective way this study has followed the guidelines and steps of some well-established mixed methods scholar, this allows accomplishing the research objective 
accurately. The qualitative data consider the trustworthiness and accuracy of the method and data as main quality criteria which were achieved by employing different procedures during data collection and analysis (Rasmussen et al., 2005). One of the main methods to check the credibility of the qualitative research is sending the interviews transcripts, themes and results back to some respondents to check if these findings match with their perceptions and answers as well as the practice. The main aim of the qualitative research is to understand and explain the phenomena from the respondents' perspective, thus the respondents who can judge the credibility of the findings (Beck, 1993). The credibility criteria emphasis on the need for the researcher to develop accurate instrument to capture the aspects of the phenomena accurately, this is because credibility focuses mainly on linking the study's results with the reality and practice, thereby, one of the main methods that used to establish and ensure the credibility is sharing the results and interpretation with the respondents, this way allow the respondents to provide feedback about the results and give clarifications. In this study, the accuracy of the transcripts and coding process were checked at different stages by the researcher and two of his colleagues who got

experience in qualitative research checked the initial code, the transcript and coding process to ensure there is no missing out any code or themes. As it was approved by the ethical committee to have people to check the coding process with the supervisory team. After that the researcher and the supervisor checked again the analysis and coding process (Silverman, 2001; Spencer et al., 2003), there was agreement between different people who coded the data concerning the main pattern of the data. Briggs, (1986) suggests using interview guide allows collecting credible and trustworthiness data as well as answer the research questions accurately. In this research, the interview guide was developed based on the research questions and quantitative stage and the participants were asked the same questions to guarantee consistency (Silverman, 2001; Krueger, 2009). Furthermore, interview schedule was sent to some academics after checking by the supervisory team. Other ways the researcher employed to enhance the quality of the qualitative study, record the interviews with the consent from the participants, (Lewis and Ritchie, 2003; Vaivio, 2008; Chen, 2012).

Thus, intercoder agreement was employed in this research to boost the trustworthiness and accuracy of the analysis of the data (Ritchie et al., 2013). Moreover, the researcher coded the data twice to ensure the accuracy of the analysis. Further, two senior colleagues (qualitative researcher) offered feedback on the final version of the qualitative analysis and results (Ritchie and Lewis, 2003; Ahrens and Chapman, 2006). In this study, the researcher follows structure and accurate procedures in order to collect the data in rigorous way by asking some professional agencies (JACPA) for help in collecting the data, and the ethical issues related to the data collection and analysis were addressed and got approval from the research ethics committee, these fieldwork steps allow improving the credibility and trustworthiness of the research data and the research process (Remmers et al., 1927). Confirmation with participants has been done in order to ensure the research findings are applicable and accurate, they appreciate the results and they confirmed that the findings are interesting to apply in their work. (Spencer et al., 2003; Roulston, 2010; Lewis and Ritchie, 2003). The researcher addressed theses quality criteria that related to the validity, reliability, trustworthiness, and credibility as main criteria for high quality of the research in mixed methods (Creswell, 2013).

\section{Qualitative Data Analysis}

In qualitative research, there are various techniques that can be employed to analyse the qualitative data. The most common techniques of data analysis involve, narrative analysis, grounded theory, content analysis, framework analysis and thematic analysis (Srivastava and Thomson, 2009), choosing one of these techniques can be influenced by various criteria include the role of the researcher, analysis focus and purpose, data access and contextualization (Silverman, 2000). In general, interview data analysis related to the category of thematic analysis which focuses on identifying and highlighting themes (or "patterns of response") that related to the collected data which allows answering a specific research questions and explaining the research problem (Bryman and Burgess, 1994; Braun and Clarke, 2006). Thematic analysis is one of the most popular methods of qualitative data analysis (Attride-Stirling, 2001; Bryman and Burgess, 2002), it can be performed in six main steps in order analyse the interview data and create which has been employed to understand the pattern of the collected data set (Bryman; 2012). This research employed thematic analysis to investigate the interview, since this technique enables explaining the qualitative data in greater details and focus on the themes and codes (Boyatzis, 1998). Conducting interview is one of the main methods of data collection in the qualitative research which can be used to understand the participants experience and perceptions (Bryman and Burgess, 2002). Attride-Stirling (2001) highlighted that interview data should be examined in a systematic way to get meaningful results. Researcher can determine common themes and codes in the data set. Moreover, thematic analysis as a technique of qualitative data, this method is useful for determining, pinpointing, analysing and interpreting the rich data in a form of main patterns and themes, this technique can be employed across a wide range of research questions and epistemologies (Grinnell Jr and Unrau; 2010). It also fits in well research such as this one aim to understand the relationship between the variables (Ivankova, 2006; Creswell, 2013). Additionally, thematic analysis employs coding and patterns to offer good explaining of the research questions by offering precise and clear steps of data analysis (Attride-Stirling; 2001). Braun and Clarke (2006) describe thematic analysis as a technique can creates logical and reasonable chain of empirical evidence, in this study thematic analysis was used as the technique for analysing and interpreting interview data. This research has followed six steps of Braun and clark's (2006) to analyse and interpret interview data through using thematic analysis as it provides accurate and methodological sound process, it is popular in analysing qualitative data. Inductive and deductive approach can be employed with thematic analysis (Frith and Gless, 
2004), employing inductive method allows the researcher to analyse the data for any emerging themes that relevant to the broad research questions and without paying attention to the theme that determined in prior studies (Braun and Clark, 2006), however, according to the deductive reasoning is more obviously analyst-focused which lets the researcher to scrutinize the data in relation to the hypothetical or quantitative results in the research problem being examined, the deductive approach allows offering more detailed analysis or particular themes or set of variables (Braun and Clark, 2006)

\section{Step 1: Becoming familiar with the data set}

Barun and Clarke (2006) propose the first phase of thematic analysis is being familiar with the data set; therefore, all interviews were recorded and transcribed in full to get details answer and understanding of the participants point views about the relationship between the ICGMs and EAQ. Transcription of data comprises of accurate observation and information of the data through listening and documenting the interview. The interviews were recorded with the permission from the participants, the researcher has read the transcripts many times in order to be familiar with the data set (Riessman, 1993). This permitted the researcher to start identifying the initial ideas and themes in the data set and also be informed and familiar with understanding the data set content in depth way.

\section{Step 2: Identifying initial codes and themes (Initial} thematic map)

Coding is the main step in the qualitative data analysis (Miles and Hubermaa, 1994) in this step the researcher assigned labels and names against the data set to accommodate the search for patterns and themes in the data (Patton,1990). According to (Boyatizs, 1998) the code is "the main element, of the raw data that can be evaluated in a meaningful manner concerning the problem". This stage starts with coding interesting and main ideas within the whole data set in a systematic way. In this research, codes were primarily identified using pre-identified themes and codes which determined from the quantitative stage and interview schedule but if any new codes emerged from the interview data, the researcher take them into consideration and specified a place in the coding process. The researcher was transcribing and reading each interview after conducting the interview to be familiar with data set as well as to find and highlight the initial codes and themes and then prepare for the next interview; coding thematic analysis requires coding interesting features of the data set (Boyatzis, 1998).

The coding process and the interview questions were guided by the research questions and quantitative results; thus, the interview was built in order to fulfill the research objectives. In this study, deductive approach was followed, and codes were initially identified using the initial codes which highlighted from the literature and quantitative stage (Barun and Clarke, 2006), thus, the researcher read and analyze the data with paying attention to the themes which are quantitative stage and previous literature have determined. Every transcript in the interview was divided into small sections in regarding to the participants' concepts, each code was allocated a discrete column and the related description organised in the same raw. The researcher assigned the same code for the similar pieces of responses that raised from different participants, which help the researcher to code and integrate (connect) the similar ideas of various respondents to gather below the same code. All interviews were analyzed in the same approach by searching for meaningful codes and themes, some examples were given about how codes process was applied in the data set,

TABLE II: DATA QUOTATIONS AND CODES

\begin{tabular}{|c|c|}
\hline The transcribe of the interview & The Code \\
\hline $\begin{array}{l}\text { "...Effective internal governance mechanisms } \\
\text { lead to reduce the risk of our audit service in } \\
\text { terms of material misstatement risk, control } \\
\text { risk, detection risk and our sampling would be } \\
\text { representative for real position of the } \\
\text { company.... }\end{array}$ & Reduce audit risk \\
\hline $\begin{array}{l}\text { "We should collect relevant, sufficient and } \\
\text { comprehensive audit evidence in order to } \\
\text { support our opinion and this is should be } \\
\text { clearly stated in our report....." }\end{array}$ & $\begin{array}{l}\text { The quality of audit } \\
\text { evidence. }\end{array}$ \\
\hline $\begin{array}{l}\text { "We can rely on and use the internal audit } \\
\text { evidence and guidance according to the audit } \\
\text { standards and JCGC in order to build effective } \\
\text { planning for the audit service....." }\end{array}$ & $\begin{array}{l}\text { the internal audit } \\
\text { evidence and } \\
\text { guidance }\end{array}$ \\
\hline $\begin{array}{l}\text { ".....by establishing effective audit plan this } \\
\text { allows us to gain good and comprehensive } \\
\text { understanding" }\end{array}$ & $\begin{array}{l}\text { Improve level of } \\
\text { understanding }\end{array}$ \\
\hline $\begin{array}{l}\text { "........good guidance from the internal audit } \\
\text { help us to focus more on the risky areas" }\end{array}$ & Valuable guidance \\
\hline $\begin{array}{l}\text { "We check to which body the internal audit } \\
\text { submit their reports and findings to ensure the } \\
\text { independence and reliability of the internal } \\
\text { audit work......" }\end{array}$ & The reporting channel \\
\hline $\begin{array}{l}\text { ".........effective internal governance } \\
\text { mechanisms allow us to build our procedures } \\
\text { and additional tests based on the internal } \\
\text { governance evidence and findings " }\end{array}$ & $\begin{array}{l}\text { Design audit } \\
\text { procedures }\end{array}$ \\
\hline $\begin{array}{l}\text { "When we collect evidence we should ensure } \\
\text { the evidence meet the qualitative and } \\
\text { quantitative criteria, qualitative which means } \\
\text { the appropriateness and relevancy but the } \\
\text { quantitative is related to the sufficiency of the } \\
\text { evidence" }\end{array}$ & $\begin{array}{l}\text { Quality of evidence } \\
\text { appropriateness and } \\
\text { relevancy }\end{array}$ \\
\hline
\end{tabular}

Coding Example This display the types of processes involved in the data coding. There were many commonalities among the participant's responses, which permitted the researcher to codes and connect the related responses of various respondents' together below same code; this permitted the formation of patterns in the entire data set.

\section{Stage 3: Searching for Themes}

In this stage the researcher should determine the main patterns and themes of the data and conceptualize the list of organized codes (Braun and Clark, 2006), under this stage the researcher can determine and combine similar code to create main theme in relative to research questions and problem. At this stage of the thematic analysis process, all codes were arranged into different categories to determine the relationship between codes and the main themes, the theme were organised based on the patterns and prevalence determine among them. For example, codes like internal audit evidence and document, applying the auditing standards and effective communications with other governance are formed the sub-theme "effective internal audit performance", the different sub-theme (e.g., internal audit competency and internal audit independence) are formed the main theme which is the internal audit factors. Thus, at this phase of analysis all codes were categorized under different themes and subthemes based on the relationship between codes, subtheme, and themes as well as their prevalence and patterns which identified between them (Braun and Clark, 2006). 
Although tables were used in the thematic analysis steps, the mind map is used in order to present the final results of the thematic analysis and explain the findings. This allows showing the robustness and systematic way of the data analysis (Braun and Clarke, 2006). The table 28 was generated as results of this step; table 28 illustrates the initial themes which developed based on the initial codes. This initial pattern involves four main themes which emerged from the qualitative data. As it can be seen in table 28 each of them involves sub-theme and cods, these initial themes were identified from the data that codes are additional developed in the subsequent phase of the analysis. The main themes were highlighted depending on their predominance and the patterns identified in the data set.

\section{Step 4: Reviewing themes: Reviewing themes (Developed thematic map)}

This stage aimed to refine the initial category of the themes, this lead to improve the quality of the analysis, the researcher in this stage was trying to refine and enhance the initial grouped theme to make the analysis more clear and comprehensive as well as to decrease the data more in a methodical approach. Braun and Clarke (2006) recommend that at this stage theme should be tested for internal consistency. According to Braun and Clarke (2006), this stage contains two main levels of reviewing the data; first of all, the researcher reviewed the consistency and coherence in relative to coded that extracted and main theme, and then check the theme in relation to the whole data set, at the end of this stage the researcher generates the thematic map. Some of the codes form the main-themes and other form the subtheme. For example, some sub-themes and codes were reviewed, refined, renamed or deleted, in this stage, for example four codes which are reduce sampling risk, reduce detection risk, reduce control risk of material misstatements have presented related theme and they were grouped and specified a new name as "reduce audit risk". Under this stage, themes, sub-themes and codes were reviewed and refined, while at this stage the level of validity of the whole data set was reviewed to check the validation of individual codes in related to the sub-themes and themes. The revised mind map illustrates the same theme. However, it shows that at this stage of analysis most of the codes were either emerged or deleted. Moreover, it was also determined at this phase of the analysis that two sub-theme (having regular discussion with internal auditor as well as effective communication with board of director) combined under one sub-theme of audit committee responsibilities (effective communication with governance bodies) as they seemed to related to the initial thematic map to audit committee performance, thus, they were grouped as a part of effective communication with governance bodies, the same process was followed to improve the remaining sub-themes. Therefore, on this stage of the analysis the code, subtheme and themes for the whole data set were prepared in order to check whether initial thematic map precisely reflects the whole data set as well as to guarantee the validity of the individual themes, subtheme and codes in relation to the dataset. Some codes and subthemes did not seem to fit to any theme; thus, they were either discard or assigned for relevant themes or subtheme. The results of this refining process are presented in the table 29 (final map for the entire), some of the codes create the main theme and others generate the sub-theme (Braun and Clarke; 2006).

Step 5: Reporting findings - Reporting thematic map (final thematic map)

In this stage the researcher further improves the initial themes and overall storytelling as well as generating clear themes and codes to report the results of the data analysis. Braun and Clarke (2006) recommend that labelling the themes is mainly for identifying the "essence" of what every theme focus on and to identify the main ideas and patterns of the theme. In this stage the researcher organised the themes and establish a coherent connection between the themes, the researcher refined and establish relationship between themes and codes at the end of the stage clear and final definitions and labels were allocated to every theme to build storytelling concerning the data set and relationship, findings of each theme are reported for one section which is divided into further theme with detailed discussion, at this phase of improvement codes like internal audit reports, applying the audit standards and effective communications with other governance were formed the sub-theme which is "effective internal audit performance" in this phase the researcher decided to move this code to another sub-them which is the competency because the data acknowledged applying the auditing standards by the internal audit reflects the capability of the internal audit in doing the audit service professionally and efficiently and applying the standards effect on the internal auditor behaviour and skills.

\section{Step 6: Writing report}

The final stage of the thematic analysis process is reporting the results of the analysis in a coherent, interesting, and succinct of telling the story of the whole data with adequate evidence from the data set, these examples have been used to support the research argument, research objectives and questions (Braun \& Clarke, 2006). Therefore, the final themes and codes would be described and discussed in detail in the following sections with vivid quotes from the data. In this section, the results for the whole data set are described with related to each theme, sub-themes, and codes in order to present reliable and rigour analysis process of qualitative data analysis with providing some evidence from the data incidents. Therefore, the qualitative stage of this study could contribute to the existing literature on EAQ and the influence of different mechanisms on external EAQ. These codes, subthemes consistently appeared as main factors related governance mechanisms appeared constantly through the data set; provide the diagram for the theme.

\section{A. The perception of External Auditors Concerning Quality of External Audit Process: Interview Evidence}

The EAQ was determined as a main theme of this study. This theme represents the external auditors understanding of the meaning of EAQ and which aspects of audit quality can be influenced by the ICGMs (see Fig. 1). According to the participants' perceptions, the quality of the audit service is more about the process and procedures of audit service rather than about specific indicators which can measure the quality of audit services as some of them stated that:

"I believe the quality of audit is related to the audit process itself and the procedures of audit service rather than specific indicators or checklist..." (EA 4). 

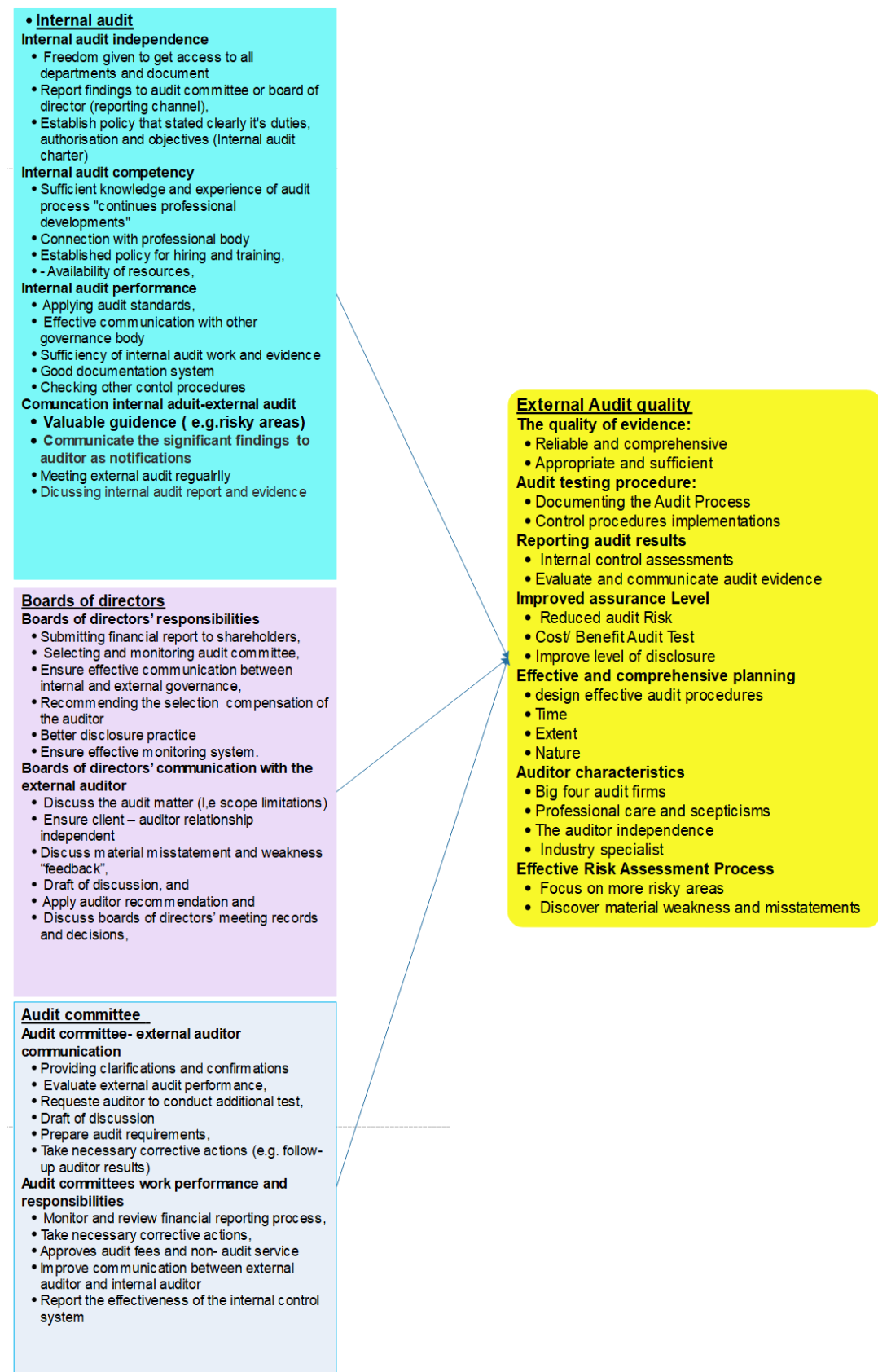

Fig. 1. Final thematic map.

"We can improve the quality and reliability of our work through performing an effective audit process" (EA 6).

The above quotations highlight that, the quality of audit is related to the process which can be influenced during the interactions with ICGMs. The process of the audit service is related to the performance of a series of actions and interactions taken in order to check and review the financial reporting process and provide opinion about the reliability of the financial statements and transactions. These can be done through performing effective audit processes. Further, one of the participants highlighted that the EAQ can be achieved through effective external audit producers:

"We should perform the audit procedures properly and effectively in order to achieve the audit objectives successfully as well as we should follow our audit methodology and developed plan which build based on auditing standards...” (EA 7). Another auditor emphasis this point as the participant stated that:
"We should follow the code of conduct and professional standards in performing our audit service to ensure that we have done a high quality audit service in accordance with the best practice...” (EA 8).

The above extracts seem to suggest that the audit quality is related to the quality of audit process and procedures that should be followed to guarantee the effectiveness of the audit. Then the results would be good enough to build the auditor's opinion as one of the participants suggested:

"The effectiveness of our work depends on the quality of the audit procedures and following the audit methodology...." (EA 9).

Moreover, the participants highlighted the role of ICGMs on improving the EAQ as one of the participants indicated:

"The ICGMs ensuring that all of us comply with the rules and professional standards that govern the audit service in order to ensure that we are performing our work professionally and effectively and we have regular meetings with them... (EA 7). Analysis of the interview data revealed 
the EAQ process theme has several sub- themes within it which are effective and comprehensive planning, audit testing procedures, reporting audit results effectively, improving assurance levels, and the quality of evidence, auditor characteristics and effective risk assessment procedures. As illustrated in Fig. 2.

Specifically, the interview findings illustrate that the external auditors perceive effective and comprehensive planning involves improving the level of understanding and designing effective audit procedures. One of auditors stated that:

"Before starting our field-work testing we should plan for our activities and we must improve the level of understanding about the firm's operation and internal control system through communicating with internal governance mechanisms..." (EA5).
This finding was supported by another participant who argues that governance mechanisms influence the effectiveness of the audit plan.

"We should interact with the internal governance mechanisms in order to design effective audit procedures because based on this interaction we can develop effective audit procedures in terms of resources and time and this in turn influence the scope and type of our procedures..." (EA11).

The majority of Jordanian external auditor agreed about the association between planning of the audit and the quality of external audit processes. Effective and comprehensive planning involves improving the level of understanding (internal control and operation systems), compliance with international standards on auditing and designing effective audit procedures. Some of the Jordanian external auditor stated that:

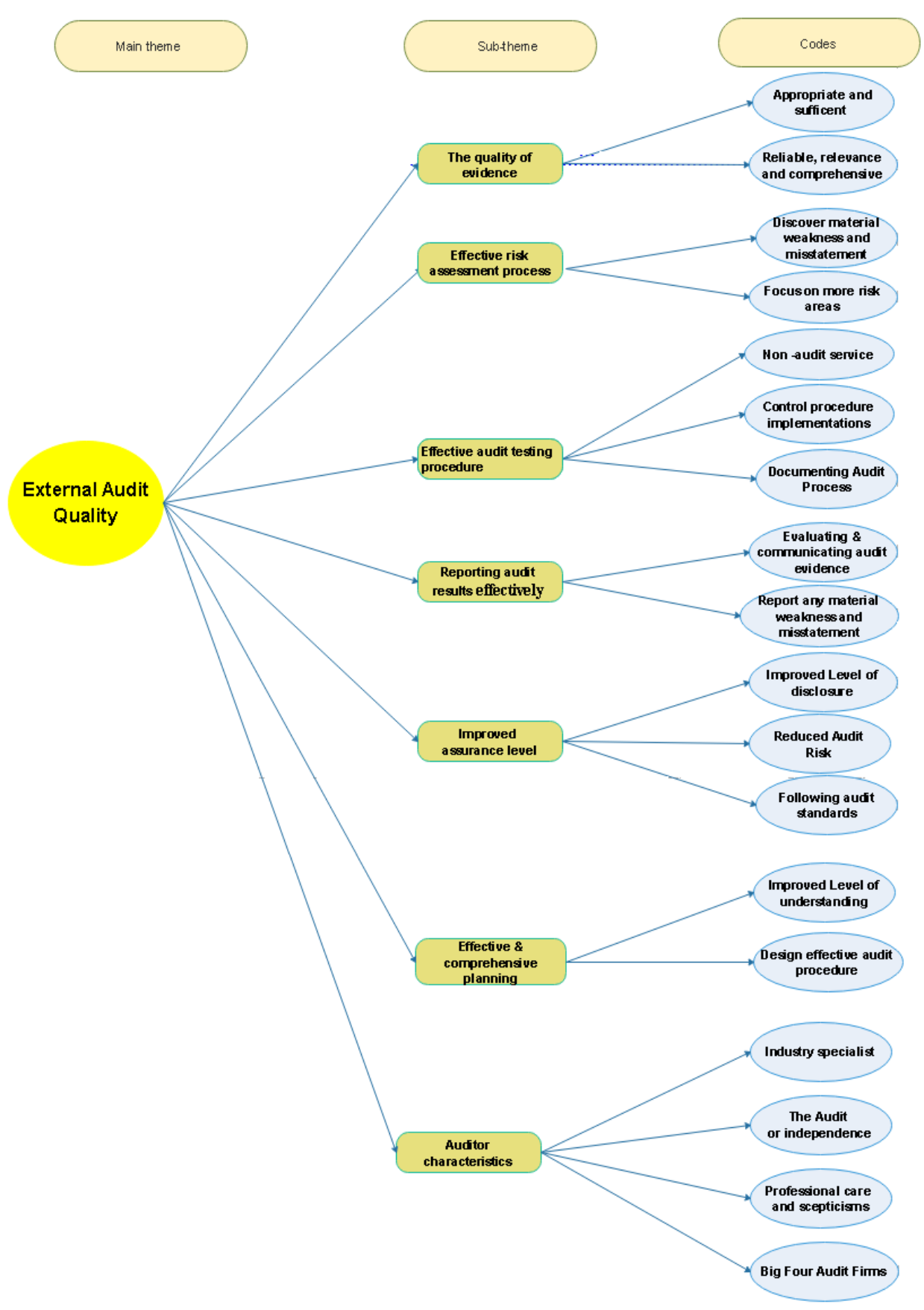

Fig. 2. Thematic map of "External Audit Quality". 
"Improving the level of understanding allows us to address and identify the material weakness in the internal control system and if there are effective governance mechanisms this allows improvement of the level of understanding and identifying the weakness and misstatement. So, we should evaluate the internal governance mechanisms and this step is one of the main steps in our work" - (EA9).

"We should obtain enough comprehensive understanding of the internal control procedures and the company's' financial transactions; then based on this understanding we can identify the weaknesses and strengths in the control system and identify our audit procedures. This can be done through communication with effective mechanisms. This allows us to achieve the audit objective effectively..." (EA 7).

The above quotations highlight that the audit service improvement in practice requires gaining good understanding of the company's control and operation system. This should be done before performing the audit procedures in order to identify the weaknesses and strengths as well as to identify to what extent they rely on their work, this is supported by another respondent who stated that:

"Through communication with effective internal governance bodies we can obtain understanding the effectiveness of internal control procedures then build good audit plan accordingly..." (EA 13).

Moreover, the interview data findings demonstrate that effective audit testing procedures are considered one of the sub-themes in respect to EAQ; it involves control procedures implementation, "quality control", a good documentation system, and not provides non-audit service. The majority of the auditors argued that the quality of the evidence varies based on the source and the way of collecting the evidence and this evidence influences the external audit service. One of the participants mentioned:

"We use internal evidence and confirmation from the client which has effective monitoring mechanisms, so the quality of this type of evidence is better than when the company has weak governance, these effects the quality of our opinion" (EA 4).

The above extracts seem to suggest that external auditors use the internal evidence which is collected by governance mechanisms only when the internal mechanisms perform good quality work, and they are good enough to build the audit procedures and improve the effectiveness of the audit service. One of the participants also suggested that they should ensure the implementation of the monitoring procedures:

"We should ensure that the control procedures existed and implemented through checking some of the transactions" (EA 10).

Interestingly, one of the auditors commented that:

"I recommend that one of the main responsibilities for us that we should evaluate the internal control system and provide recommendations to improve the effectiveness of the control procedures as this is not one of our objectives. As external auditors we evaluate the control system to design our procedures only; not to provide opinion or recommendations about the effectiveness of the control procedures..." (EA 8)

Furthermore, interview findings demonstrate the documentation system should be comprehensive, accurate and address all the audit procedures as this can support the auditor's opinion as some of the participants indicated:

"We should document the whole audit process properly and effectively to use them in expressing our opinion and building the report with enough details and references and we need to use these as evidence to support our opinion and we can use them to show our work procedures to anyone who ask us such as audit committee..." (EA 8).

"It is important to document the whole audit process because it is one of ISA which states specifically the requirements of documentation, and this supports our opinion" (EA 12).

"We do care about the documentation system as it should be full and comprehensive, especially to protect ourselves from any lawsuit in the future as lawsuits have been increased against us recently..." (EA 7).

Analysis of the interview data suggested that the auditor should check the control procedures implementation in order to ensure the quality control as noted by some of the participants:

"We should ensure that the control procedures existed and implemented in order to ensure that the client has the control procedures and it applies these procedures effectively in every single transaction..." (EA 2).

"As auditors we review the organisation's structure and the monitoring procedure over the financial reporting in the client, but this is not enough for us, we need to ensure the procedures are really applied through checking a sample of the transactions..." (EA 5).

The above incidents appear to indicate that the external auditors review the process of the control procedures through checking samples of the transactions and testing the control procedures over these transactions. Then they decide to rely on the internal governance mechanisms work. This can improve the quality of control procedures and in turn influence the quality of the external audit. Interestingly, according to the participants' experiences and perceptions, the quality of the audit process depends on the quality of the evidence. They also highlighted that there are different criteria to assess the quality of the evidence which involves the source of the evidence (internal and external) and the type of the evidence (either qualitative or quantitative). One of the participants stated that:

“... while we are gathering evidence, we should ensure that the evidence meets the qualitative and quantitative criteria; qualitative which means the appropriateness and relevancy but the quantitative is related to the sufficiency of the evidence..." (EA 3).

"Effective internal governance mechanisms can help us in improving the quality of the external audit evidence by focusing on collecting evidence from the riskier areas and collecting comprehensive evidence..." (EA2).

The above quotations highlighted that there are different criteria to assess the quality of the evidence and this evidence is influenced by the effectiveness of the internal governance mechanisms, indicating the source of the evidence (internal and external) and the type of the evidence (quantitative and qualitative). This suggests a possible link between the quality of evidence and the effectiveness of ICGMs. Further, based on the participants' knowledge and views, this study found that appropriateness and sufficiency can be achieved through 
interacting with effective governance mechanisms. It also indicated that there are different criteria to identify the sufficiency and appropriateness of the audit evidence. The majority of the auditors argued that the quality of the evidence varies based on the source and the way of collecting the evidence which is influenced by the effectiveness of the governance mechanisms and this evidence influences the external audit service. One of the participants mentioned that:

"Through our evaluation of the internal governance mechanisms we work with them in order to collect comprehensive, reliable and enough evidence that addresses all the areas in the company especially risky areas..." (EA 3).

Thus, evidence collected for the client that has effective governance mechanisms are better quality than when the client has weak governance mechanisms. Moreover, the findings indicate that the auditor can achieve effective and a high quality of audit service by using effective audit testing procedures which can be done through collecting high quality evidence. In order to perform a high quality of audit service the auditor can use the evidence of the internal governance mechanisms as some of them highlighted that:

"We focus on collecting high quality evidence which are (relevant and comprehensive) in order to be able to provide reliable results. Then we can provide high quality of audit services. Thus, our opinion represents the real position of the company..." (EA 3).

The data consistently indicate that the experience and perception of the auditor concerning the quality of audit process reflects on the quality of the auditor's opinion. This is reliant on the quality of the audit evidence; thus, improving and promoting the quality of audit evidence which reflects on the quality of the auditor's opinion. One of the big four firm's participants emphasized this:

"We should collect reliable and relevant evidence to support our opinion thus we can build credible opinion based on this evidence... (EA 2).

The importance of the external auditor's characteristics was indicated by many participants to have an effect on the level of the EAQ. The analysis of the interview data determined that this theme involves the auditor's independence, industry specialism, professional care, and scepticism, and being from one of the big four audit firms.

The interview findings illustrate that the external auditors perceive that the internal governance mechanisms ensure and monitor the independence of the auditor which can have an influence on the quality of the audit service as some of the auditors emphasized on that as some of them highlighted:

"... based on my experience in the Jordanian context in small local audit firms and the big four, the big four provide independent assurance more than local audit firms assurance services as during my work in the local firm we used to prepare some reports such as the tax report and I believe the lack of independence specifically in some small local firms lead to preventing us from performing a reliable assurance service..." (EA 11).

Further, the significance of the auditor's independence was highlighted with responses from some participants as some of them stated:

"We should not have a mutual interest or conflict of interest in order to perform an effective audit service...".
"There is a serious problem which is the lack of independence in most of the companies as most of the auditors perform non-audit services such as setting control procedures, evaluating internal control effectiveness which influences the quality of our work... (EA 11).

The participants highlighted that the quality of the audit process is influenced by the industry specialist which may result to a more quality output of the audit. As some auditors highlighted that:

"The industry specialist is important for us because we should understand the nature of the companies' activities effectively and this allows us to understand the risk that is related to these transactions and the nature of these transactions..." (EA 5).

"... We can perform an effective service if we are experienced in the sector of the client because each sector has different types of transactions and different nature of the operation and we can get some benefits from the risk assessments and where the risky areas in the company..." (EA 13).

The majority of interviewees acknowledged that in the Jordanian context, the type of the company has an effect on the quality of the audit service. This finding was supported by another participant who claims that the quality of the big four firms is better than the quality of the small local firm:

"I have worked in a small local audit firm and one of the big four in Jordan; I have found a vast difference in the quality of experience between these two companies. As well the big four firms provide only audit services instead of providing some accounting recording service, like small local companies do which can influence the quality of the audit work..."(EA 7).

"In Jordan almost all the big public companies and banks have been audited by big four companies because they believe that the big four are more independent and they have better experience and quality of work" (EA 12).

Thus, the big four audit firms are performing a better service than the local firm, thus, the big four auditor performs an effective service in Jordanian context because they have foreign partners. One possible explanation is that the big four in the Jordanian context are more trustworthy and provide a more reliable service. These elements reflect the EAQ in terms of effective planning procedures, audit testing procedures, reporting audit results effectively, improving assurance levels, and the quality of evidence, auditor characteristics and effective risk assessment procedures.

\section{B. Boards of Directors' Responsibilities and Audit Quality: Interview Evidence (2300 words)}

This section highlighted and explained the perceptions of the Jordanian external auditor concerning how the board of director can influence the quality of external audit process- in what ways and what are the board of director mechanisms. Boards of directors was acknowledged as one of the main themes through the data set which specifies external auditor understanding and experience concerning to different mechanisms of internal governance which could enhance the quality of audit process (See Fig. 3). Analysis of the evidence from the interview has shown the board of director theme has two sub-themes (responsibilities boards of directors and boards of directors-external auditor communication) which 
are constantly appeared as main elements associated to boards of directors in the data set.

Interview data findings demonstrate boards of directors has two main monitoring role regarding the overall governance system and audit process which are boards of directors responsibilities and boards of directors-external auditor communications as can be seen in Fig. (3), this sub-theme was emphasized from the participants" point view concerning board of director responsibilities concerning their role in improving the EAQ, boards of directors responsibilities involves different codes such as approve and submit financial report to the shareholders, ensure audit client relationship is sufficient independence selecting and monitoring audit committee, recommending the selection and compensation of the auditor, better disclosure practice and ensure effective monitoring system, as one of the respondents emphasis on the importance of the role of the boards of directors in the monitoring system as he stated:

"I would say the board of director play key monitoring role over the financial reporting system; this allows us to improve the reliability and accuracy of the financial information and the confidence about the process of producing the financial report..." (EA 2).

Some respondents indicated that the board of directors are performing monitoring activities over financial reporting and audit process to ensure quality of the financial reporting and auditor report.

"I believe that the board of director can help us in improving the quality of our work, through direct interactions and communications with them, as well as through some of the board responsibilities in terms of monitoring role and ensuring the full disclosure of the company transactions...." (EA 4).

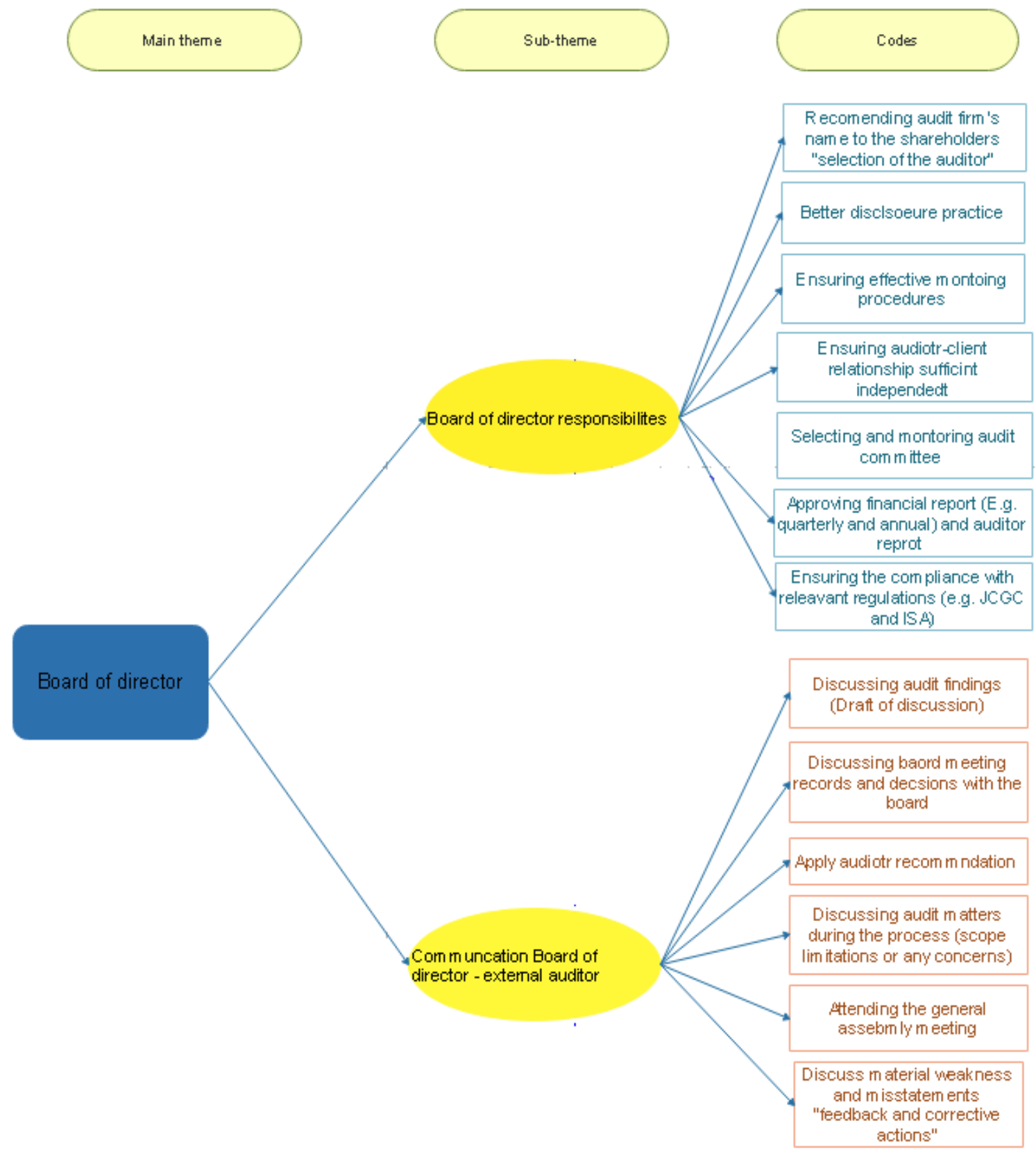

Fig. 3. Thematic map of 'board of director'. 
Moreover, the significance of the role of board of director in terms of ensuring effective monitoring system perceived by many respondents to have an influence on the quality of audit process. The majority of respondents agreed about the link between the role of the board of director in terms of ensuring effective monitoring system and external audit quality, as some of the participants highlighted that:

"The board of director ensure the effective monitoring role over the financial reporting system through monitoring the quarter, semi-annual and annual report which allow improving the monitoring process over the financial reporting throughout the year and if we have any questions or concerns about all these reports, we can communicate with them to improve the quality of our work and opinion........" (EA 11).

The analysis of the transcribe has shown the board of directors discuss the critical financial and control issues and they discuss the audit findings with the audit committee and external auditor as some of the participants called this "draft of discussion" but other called it "management letter".

"... discussing the audit results with the board of director allow us to improve the disclosure and correct some of the misstatement as well as improve the control weaknesses before issuing our report and provide more disclosure by the board of director about some transactions ......." (EA 12).

"... we need to interact and cooperate with the internal governance bodies such as board of director in order to perform effective audit service in terms of cost, time and resources..." (EA 10).

This allows improving the quality of financial report, level of disclosure and transparency so we can improve the quality of audit report that issued to the company, as one of the auditors emphasised that:

"... There are certain issues and concerns we should communicate directly to the board of director for example if we have any concerns about our relationship with audit committee or board meeting records and decisions..."

The evidence from the interview also suggested boards of director's responsibility in terms of submitting financial report to the shareholders as indicated by one of the participants:

"The board of director should review, approve and submit the financial report and auditor report which allow improving the quality of financial reports, level of disclosure and transparency through reviewing and checking these reports, so we can improve the quality of auditor report that issued to the company..." (EA 5).

"I believe the board of director play vital role in preparing, submitting and communicating the financial report and review auditor findings then submit these reports and findings to the shareholders on time and allow them to take the right decision in the right time and this is our aim as well..." (EA 7).

Further, the significance of ensuring better disclosure practice highlighted with responses from some participants as one of the main elements of the board responsibilities. The analysis of the interview data demonstrate that it is important role of the board to set the disclosure policy and ensure the full disclosure and transparency, as one of the participants identified that:

"...Our discussion with the board of director in conducting the audit allows us identifying and rectifying the main problems in the financial reporting system and weakness in the internal control procedures as well as corrects some misstatements before issuing our report..." (EA 8).

"In case I find any decisions for the boards or future plan for the board meeting records and there is not enough disclosure about them for the shareholders, so we ask the board for more disclosure and we discuss the board meeting records with the board..."

"We do ask the board of director for more disclosure about some of the transactions especially for those need more disclosure and in most cases, they respond to our requirements..." (EA 9).

The above quotations suggest that the discussion and communications between the external auditor and board of director can improve the disclosure and transparency of the board actions and decisions. This leads to improve the level of disclosure about some aspects of their decisions and activities.

Furthermore, boards of directors-external auditor communication; draft of discussion, discuss the audit matter (i.e., scope limitations), discuss material misstatement and weakness "feedback and corrective action", draft of discussion, attending general assembly meeting with the auditor, apply auditor recommendation and discuss boards of directors' meeting records and decisions. The importance of the Boards of directors' role in terms of applying the auditor recommendations noted by many participants to have an effect on the boards of directors' communication with the external auditor and thus influence the level of EAQ. An auditor in one of the big four audit firms emphasised this:

“... board of directors play vital role in respect the audit process, because the board of directors can improve the applications of our recommendations and apply the control procedures on these points..." (EA 6).

The above extract seems to suggest that applying the auditor recommendations should be as follow up actions to the auditor findings which allow the auditor to enhance the quality of the financial reporting and control procedures accordingly based on the auditor results by applying the auditor recommendations, as one of the participants also stated that:

"... The board of director helps us through implementing the corrective actions based on the draft of discussion which issued by us..." (EA 11).

The previous incident highlights that the board of director can apply the auditor recommendations then they can get actual results and improvements based on the auditor findings. Further, the significance of the role of the board of directors in discussing the audit matter was highlighted with responses from some participants. The analysis of the interview data demonstrate that discuss the audit matter (i.e., scope limitations).

"Our discussion with board of director mainly in order to avoid any scope limitations or if there is any internal body reject giving us any information required" (EA 13).

Another auditor argued that the boards of director's role in terms of ensuring the independent are necessary factor that influence external auditor's reliance and audit service. One of the participants mentioned:

"The board of director is responsible to ensure the independent of our work by controlling our communications 
with audit committee and other internal governance bodies..." (EA 12).

"The effective board of director ensure that there is no existence of conflict or mutual interest between different bodies inside and outside the company then we provide and perform independent opinion and service..." (EA 2).

"We provide our recommendations based on the audit results to the board of director and audit committee then they to apply our recommendations" "apply auditor recommendation and this is improved our results and recommendations" (EA 11).

It can be concluded that according to the interview data the participants suggested that effective communications and discussions with board allow them to perform effective audit service.
C. Audit Committees Work Performance and Audit Quality: Interview Evidence

The data showed constantly that audit committees as one of the main themes through the different interviews data, which indicates the respondents' knowledge and experiences concerning to various mechanisms of internal governance which could have influence on the quality of audit process, it has different sub-themes and codes regarding to this theme and they were presented in this section to comprehend and explain the effect of audit committees on the quality of audit process. Analysis of the interviews data revealed the audit committees' theme has two main sub-themes (responsibilities audit committees and audit committees -external auditor communication), reported below as can be seen in Fig. 4, data about audit committee's patterns is divided into two main sub-themes and various codes,

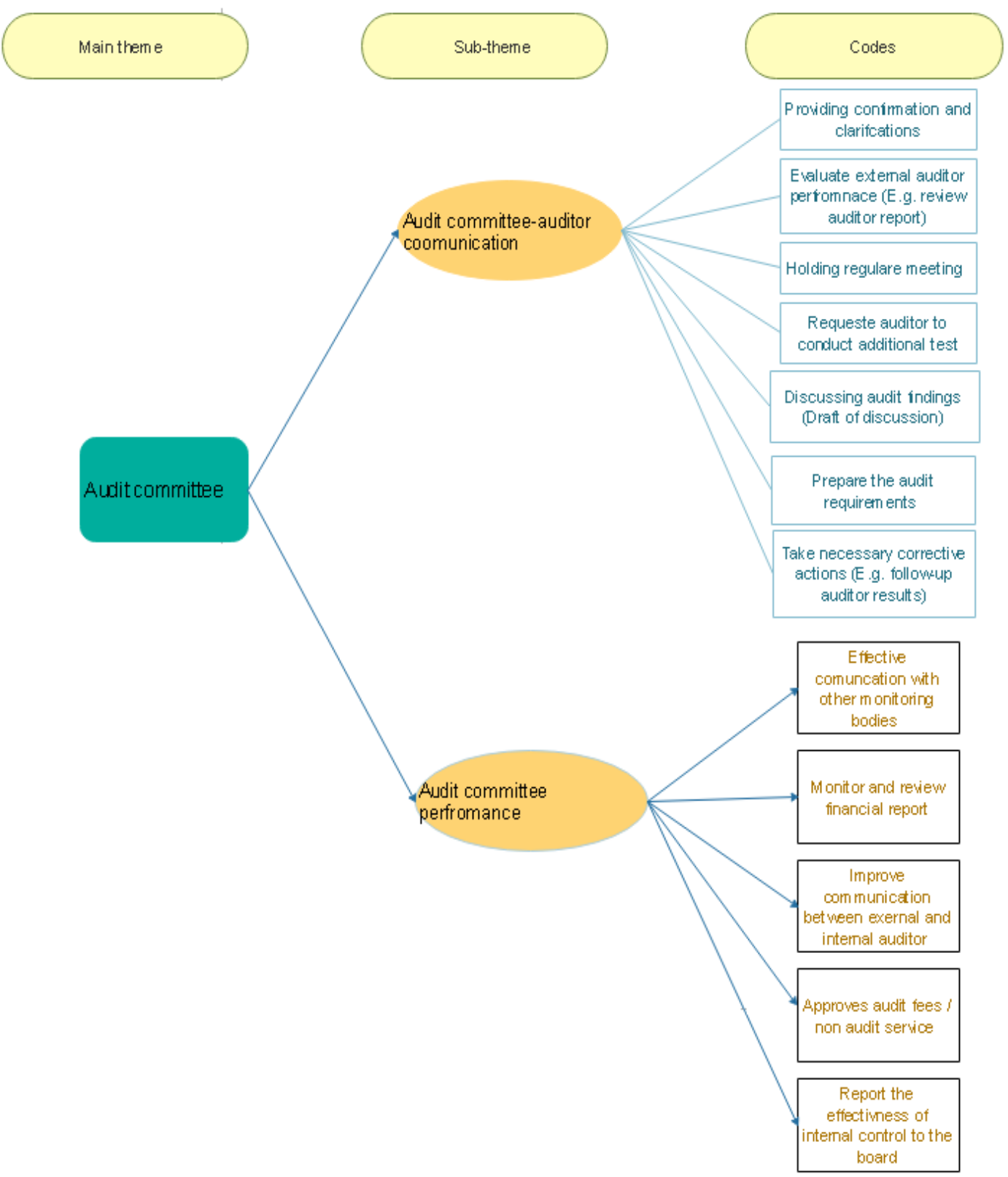

Fig. 4. Thematic map of audit committee's. 
Interview data findings demonstrate audit committee plays vital monitoring role over the overall governance system and audit process, audit committee external auditor communication was identified as main element in relation to audit committee as governance mechanisms, audit committee- external auditor communication was highlighted from the respondent perceptions concerning how audit committee can influence the quality of audit process, it involves providing clarifications and confirmations, evaluate external audit performance, draft of discussion and prepare audit requirements, request the auditor to conduct more tests, holding regular meeting and take necessary actions, these roles of audit committee in terms of communication between the external auditor and audit committee as main roles that can influence the quality of external audit process, based on the respondents perceptions (Alawaqleh and Almasria, 2021). An overwhelming majority of the interviewees expressed that evaluate external audit performance and provide feedback is one of the main roles of the audit committee which can improve the quality of the audit process. The evidence from the interviews suggested that the audit committee play vital role in the external audit service through evaluating the external audit work and providing auditor with the feedback, for example some of the respondents indicated that:

"During the meeting with the audit committee some of its members asked us for more details and further tests concerning specific findings and we perform additional test based on their requests..." (EA 11).

"We start our meeting through discussing particular issues and concerns with the audit committee..."

"We have been asked in different point by some audit committee to perform additional tests in order to provide more assurance especially when they have concerns about specific transactions or they have questions about our results ..." (EA 4).

The majority of the participants confirmed that the committees' responsibilities are important for external auditor in terms of asking them to take a large sample size or amending the level of materiality. As indicated by one of the participants:

"When the audit committee has some concerns about some issues that related to the financial reporting process of the level of control that they highlighted and asked us to focus more during our audit work and provide more details and sometimes collect more evidence..." (EA3).

The above quotations recommend that the audit committee can ask the external auditor after evaluating the audit results and performance for more details for example they can ask the auditor to conduct additional tests as mentioned by the majority of respondent.

Interestingly, one of the auditors suggested that the audit committee can evaluate their performance but without any interfere in their work:

"We held regular meetings with the audit committee, but we don't allow them to tell us what we should do and what we shouldn't do, but we discuss with them any limitations in our scope of work and unavailable information..." (EA 7).

"We discuss with the audit committee members the initial results in order to get explanations and confirmations from them about the results and to do more tests based on the discussion..." (EA 2).
This is supported by two respondents who described the importance of the draft of discussion in communicating and discussing their findings and get feedback from the audit committee as they indicated:

"We submit the draft of discussion to the board of director or audit committee to get their perceptions about the results and we work with them on follow up action to improve the quality of financial reporting disclosure before issuing our final report..." (EA 12).

"Internal audits help us more in the fieldwork and planning stage but the audit committee and board in the planning and discussion of the audit findings..." (EA 7).

Moreover, the interview data findings demonstrate that the external auditor perceive that preparing audit requirements by the audit committee as significant factor that can influence the quality of audit process as noted by some of the participants:

"Before starting our course work, we ask the audit committee in the initial meeting to prepare and provide us with the audit requirements for example we ask them for some documents related to the company sector, details about the assets and liabilities, board and audit committee meeting records, contingent liability, tax details and company accounting policy..." (EA 2).

"One of the main things that we ask the audit committee to do is preparing audit requirements as well as they guarantee that we comply with the audit standards and regulations in checking these documents..." (EA 11).

In addition, the auditor perceived the importance of audit committee in getting to understand about the client control environment as some of the respondents suggest that audit committee can help them in improving the level of understanding of the client operation and control process, as one of the auditors identified that:

"We can get comprehensive and effective understanding about the internal control environment and operation system through helping from the internal governance mechanisms especially from the audit committee, this allows us to use the limited time and resources effectively through the planning process..." (EA 5).

The importance of the role of audit committee in terms of taking necessary corrective actions was indicated by many participants to have an influence on the level of EAQ. The analysis of the interview data determines that taking follow up and corrective actions are important for improving EAQ as some auditors highlighted this:

"During conducting the audit service, we should communicate the audit committee regularly in order to perform our service effectively and we consider the audit committee as a reference body when we need any help or more information about some transactions or to correct any misstatement as well as to improve the weakness of the internal control before issuing the final report..." (EA 7)

Interestingly, one of the auditors indicate that not all the audit committee are active in taking corrective actions and the auditor should ensure that the audit committee has taken corrective transactions according to the internal and external audit results,

"... the audit committee should take follow up actions for the internal audit report and results, however in most of the Jordanian companies that we have audited there is no practical steps that have been taken by the audit committee or 
board of director in order to improve any weakness, thus, we recommend to the Jordanian regulators to set strict instructions and guidelines regarding the follow up actions for the internal and external auditors' findings.. "(EA 9).

"...taking corrective actions by the audit committee help us in improving the quality of financial reporting system and control procedures before issuing the auditor report; we should ensure the applications of the follow up actions in the reality..." (EA 7).

The interview findings indicated that "audit committees work performance and responsibilities" also have an impact on EAQ process, the auditor perceived the audit committees work performance and responsibilities involve enhance communication between external and internal auditor, monitor and review financial reporting process, effective communication with other monitoring bodies, approves audit fees and non- audit service as well as report the effectiveness of the internal control system.

Moreover, the main role of the interview data findings demonstrates that the role of audit committee in terms of reviewing financial reporting and monitoring system as one of the main factors that could improve the quality of audit process. One of the respondents indicated:

"We use the work and evidence of the audit committee as the main monitoring bodies inside the company over the financial transactions and we discuss with them any weakness in the financial monitoring system" (EA 5).

"One of the main objectives for our work is to ensure the monitoring system in the company is existed and implemented to prevent or detect any fraud and the audit committee help us in achieving this objective through providing us with documentations that confirmation that the internal bodies are applying these procedures through providing us some evidence and help us to test sample of theses control procedures..." (EA 11).

Other auditors argued that the role of audit committee in terms of approving audit fees and non- audit service is one of the main factors that could improve the quality of audit process. One of the participants mentioned:

"One of the main roles for audit committee is to approve audit fees and non- audit service and they should ensure that there is no mutual of interest between us and any internal governance bodies..." (EA 6).

"We should get the approval from the audit committee for non-audit service and audit fees..." (EA 4).

Furthermore, one of the participants highlighted the importance of the effectiveness of the communication between them would enhance the EAQ:

"If we are specialist in the industry of the client so we can talk the same language of the audit committee and board of director members because most of the members are from the same background of the sector, I mean if we audited pharmaceutical industry, we should have knowledge about this industry as most of the audit committee or board of director are from the medical background..." (EA 10).

Furthermore, the interview data findings demonstrate that reporting the effectiveness of the internal control system is considered one of the main roles of audit committee which has impact on EAQ; it involves evaluating control procedures implementations "quality control", as one of the participants mentioned:
"One of the main roles which clearly stated our report that we evaluate, and report does the company has effective internal control system and the audit committee review this control system and report any weakness which allow us to focus more on these weakness..." (EA12).

The above quotations support the codes; themes and subtheme from evidence extracts form the interview data in order describe the role of audit committee in improving the quality of external audit process.

\section{Internal Audit Factors and Audit Quality: (Interview Evidence)}

Internal audit factors were recognized as one of the main themes through the different interviews which indicates the external auditors' knowledge and experience concerning the various mechanisms of internal audit which help improving the quality of the audit process. The analysis of the interviews data reveals three main sub-themes (internal audit independence, internal audit performance and internal audit competency). Consistently, these factors appear as main elements associated to internal audit function in the data set; hence, this section highlights the sub-themes in detail.

Specifically, the interview data findings reveal internal audit performance embodies different codes which can influence the EAQ like, effective communication with other governance bodies, sufficiency of internal audit work, checking other control procedures, applying auditing standard and good documentation system. Internal audit performance was indicated by many participants to have an effect on some aspects of EAQ. Some respondents emphasized that they are performing some of the activities and duties which are similar to the activities of the internal auditor as internal auditor and external auditor require maintaining high quality of work in terms of risk assessment, planning and collecting evidence. An auditor in one of the firms emphasised this:

“... Since the internal audit help us in the risk assessment process through highlighting the main weakness and risky areas in the internal control system this allows us to provide good quality and reliable audit report as one of the main responsibilities for us and clearly stated in our report is to evaluate the effectiveness of the internal control procedures and what are the risky areas..." (EA 7).

"We should check does the internal audit perform the audit activities based on the professional standards..."

The previous incidents indicate that how the Jordanian external auditors use the evidence and the findings of the internal audit in terms of risk assessment process while maintaining professional standards in doing their job. Thus, the external auditors can improve the effectiveness of the risk assessment and allow the external auditor to focus the audit procedures on most risky areas through highlighting them. They supported their perceptions about the internal audit function in relation to risk assessment process in Jordan by citing trusted sources of information, a respondent in an audit firm confirmed this when he said:

"We should follow the ISA and there are specific standards which are related to risk assessment for example ISAs 315 which guides us how to use the risk assessment and evaluation which was performed by the internal audit..." (EA $1)$. 


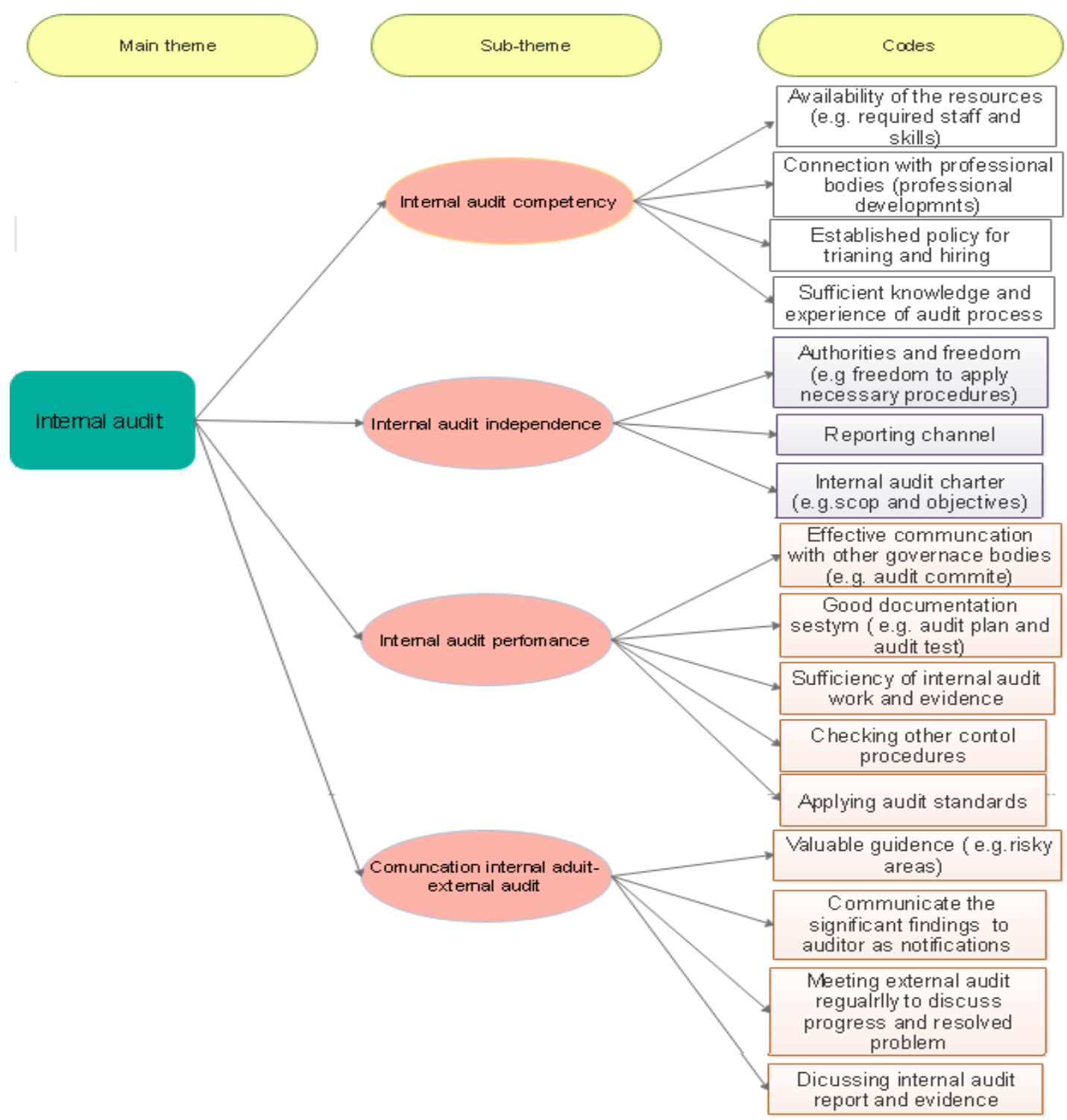

Fig. 5. Thematic map of "internal audit factors.

Although the auditing standards allow the auditor to use the evidence which collected by the ICGMs and the ICGM are important in collecting high quality audit evidence but some of the auditor said that they don't use the evidence which collected by the weak governance mechanisms and the length time required to fill documents, some auditors rely on their intuitive judgment and work as some of the auditors stated that:

"I don't use the evidence which collected by the internal auditors because there are various documents that I should fill and there are different procedures that I should apply, thus, I prefer to collect evidence by myself instead of using the internal audit evidence and filling these documents..." (EA4)

"If we rely on the work of the internal audit, we should fill some forms and documents to comply with Jordanian regulations and audit standards, so I prefer to do the work by myself instead of filling these documents...." (EA 7).

“... If I rely on internal audit evidence I need to check and report how the internal audit collected the evidence, the sample strategy and the qualifications of the internal audit then I can decide to what extent that I can rely on the work of internal audit..." (EA 12).
The previous quotations indicated although there are auditing standards allow the external auditor to use the internal audit work and some of the auditors decide not to rely on the IA work and not follow the standards. One possible explanation why some auditors they don't follow the auditing standards in terms of reliance on internal audit work as they emphasise on that there are complicated procedures that they have to do it in order to rely on internal audit work, thus, they would spend the same time and efforts in collecting the evidence. The above extracts seem to suggest that some auditor based on their personal judgments they don't prefer to rely on the work of internal audit even though the standards allow them to do that.

Furthermore, the significance of the internal audit competency was highlighted with responses from the majority of the participants. The analysis of the interview data demonstrate that internal audit competency involves some codes such as sufficient knowledge and experience of audit process, connection with professional body, established policy for hiring and training, define what skills are required availability of resources.

Analysis of the interviews data revealed that they check the internal audit is connected with professional body because 
this reflects on their performance as highlighted by one of the participants:

"We check if the internal audit is connected with professional body or if it is outsource or in source because if they are related to professional body then they would apply the auditing standards properly in Jordan there is some companies use outsource internal audit then we need to contact them directly..." (EA 10).

However, one of the auditors highlights that there is need for active professional body for internal auditor in Jordan, as he stated:

"In Jordan we don't have active professional body for internal auditor, so we need to have such kind of professional body in order to improve the quality of internal audit work and monitor their work then we can trust their work and rely on their work..." (EA 11).

Most of the participant emphasized on the importance of the effective documentation system of the internal audit on their work and their decisions of reliance on the internal audit work as stated by one of them:

"... good documentation system of internal audit allows us to get access to the information needed accurately and effectively thus, we can trust and use their evidence and results because they have supported them by documents and references to their evidence" (EA 7).

Moreover, the data highlighted that internal audit - external audit communication as one of the main factors that the internal audit can influence on the quality of external audit process, the analysis demonstrate that the communications between them include different ways, valuable guidance, regular meeting, communicate significant findings to the external auditor as notifications and discuss internal audit evidence and report.

Further, guidance from a competent internal auditor to provide information and direction for the main risky areas and the weakness in the company were highlighted as an important factor. Since most of the participants emphasised on the importance of the guidance that they receive from the internal audit as some of the auditors stated that:

"... the valuable guidance that we receive from competent and effective internal audit concerning the main risky areas of the financial reporting system and weakness in the control system this allows us to focus on the riskiest areas instead of spending our time and resources on less risky areas, thus we can provide high quality and effective audit service and our work can be comprehensive...." (EA3).

“...Proper guidance from effective internal audit help us to focus more on the risky areas as it can be as form of regular meeting and communications to discuss the findings and the key risky areas and weakness" (EA 12).

“... Internal auditors report focuses on the weaknesses of the company and risky areas, then provide recommendations accordingly, and this will help us to focus on these areas and do more test...". (EA11).

"We should examine some of the items that internal auditor has already tested them to check do their results and supported documents are reliable and to what extent we can rely on them..."

"...we discuss with the internal auditor some weakness in the control procedures and have they recommended any solution to the audit committee or the board to take any further actions, this discussion allows us to reduce the duplications..."

The above quotations highlighted that if the internal auditor's performance help the external auditor in conducting audit service as they know the company control system more than the external auditor; this is consistent with the auditing standards. Further, another auditor indicated that:

"I would say valuable guidance from the internal audit based on their results and tests has contributed to strengthening the role of internal auditor in helping us, especially in determining weaknesses in the internal control system and make recommendations for the improvements in the system and working to strengthen it..." (EA6).

Internal audit independence was indicated by many participants to have an effect on the quality of audit process, involves, freedom given to get access to all departments and documents, report findings to the audit committee or board of director, and establishes policy that stated clearly internal audit duties which is internal audit charter. The findings from the interview show that the participants perceive the internal audit should provide objective and independent assurance, as noted by some of participants:

"We should ensure the internal auditors performing their service without any interfere form the management before relying on the work of the internal audit because they should not report to those who they audit..." (EA 12).

In addition, interview transcribe demonstrate that external auditor perceives the internal audit charter as main source of data for checking the internal audit independence and internal audit objectives as perceived by some of the respondents:

"For each company that we are auditing they should have distinctive charter which states clearly the internal audit aim and structure of the internal audit work, communicating and authorization..." (EA 9).

"We should review internal auditor report, internal auditor charter, reporting and communications channel as well as the aim of the internal auditor should be clear in terms of checking the internal control procedures" (EA 4).

This indicate that internal audit report was highlighted as important factors in influencing the internal audit performance, this also help on improving the quality of external audit process. The previous incident also highlighted that these external auditors believe that the internal audit charter is the main source to check the internal audit competency and objectivity. They supported their views about the internal audit function in relation to the audit quality process in Jordan by citing trusted sources of information, as one of the respondents mentioned:

"We should follow the International Standards on Auditing (ISA) and there are specific standards for example (ISA 610) guides us how to use the work performed by the internal audit and how to assess internal audit performance, competency and independence and we can apply and follow these standards in Jordan...". (EA 7).

It can be concluded that according to the interview data the participants suggested that effective internal audit function allow them to perform effective audit service as noted by some of them:

"Effective internal audit function should be objective in conducting their work, this allows us to use their evidence and 
work to perform effective audit procedures in terms of cost, resources and time...."

"We consider internal audit as independent internal monitoring body which can offer recommendation to the boards and audit committees and to us as external auditor, the guidance from the internal audit allow us to focus more on more risky areas, addressing the most significant audit matter and respond to assessed risk...” (EA 9).

Analysis of the interviews data shown that there are two main distinguishable perceptions concerning using internal audit evidence and work which held by the participants, as explained earlier some of the respondents claims that they prefer to use their evidence and perform all the audit procedures by themselves, however, other group of respondents suggested that internal audit help improving the quality of audit procedures by assisting the auditor in risk assessment, planning and fieldwork testing. It seems that external auditor considers the influence of work performance of internal auditors only when independence and competency are high. It can be concluded that the previous extracts seem to suggest that if the internal auditors checked the internal control procedures based on effective planning, enough sample then the quality of work would be good enough to build the audit procedures and improve the effectiveness of the audit service.

\section{IMPLICATIONS FOR THE PRACTITIONERS}

Audit and governance mechanisms research can offer empirical perspective for the importance of corporate governance process and system particularly in ascertaining how specific mechanisms can improve the EAQ. The results of the study provided some implications that could help the external auditors in improving the service that they perform. Specifically, the findings highlighted the significance of the internal audit in improving some aspects of the quality of external audit process (Almasria, 2021). The result of this study also provides insights and explanations about the influence of the internal audit performance, competency and independence on the EAQ as they indicate that the internal audit performance can improve the quality of the external audit service in terms of collecting comprehensive evidence, using internal audit findings and providing valuable guidance. This implies that internal auditor can aid the external auditor decision making in terms of risk assessments, and weakness of control procedures. The results of the study recommend that the external auditors are aware of the 291 importance of the ICGM in improving the effectiveness and the quality of the external audit process, however, they believe that these mechanisms should be more professional and independent in performing their work, Specifically, the results of the study indicate that it is necessary for the external auditor to ensure the independence of the internal auditor and this allows them to trust their findings and evidence (Almasria, et al., 2021). The internal auditors in Jordan need to be more independent and competent in a way that allows the external auditors to use and trust the work of internal auditors. Further, the participants emphasized on the importance of the role of audit committee in the quality of external audit process, as the results indicate that the audit committee play a vital role in discussing to what extent the external auditor can rely on the internal auditor and how the external auditor can communicate with the internal auditor. Specifically, the results recommend that the audit committee must apply auditors' recommendations, as the Jordanian audit committee play a vital role in improving the quality of the external and internal auditor communications, as well as through applying the recommendations of the auditor, however, some participants indicate that the audit committee in most of the companies are not active in applying their recommendations (Alawaqleh and Almasria, 2021). The results also suggest what cooperation is needed during the audit process between the ICGM and external auditor who should take into consideration the work that has been achieved by ICGM in terms of monitoring activities and communicate with them accordingly. Furthermore, the results also suggest that ICGM can assist improving the EAQ during the planning and conducting the audit service such as the evidence that collecting by the internal auditors and the guidance from the internal auditor to the external auditor, in this case high EAQ reduce information asymmetry, improve level of control and disclosure (Lawrence et al., 2011), the board of director, audit committee and internal audit are pursuing to achieve these objectives, thereby all these parties concern and work to improve the quality of auditor report and prevent audit failure. The responsibilities of the board of directors have a major influence on the work of the external auditors as the results of the board of directors can enhance the communications process, reporting the audit results, and the disclosure of the financial reports which reflect on improving the EAQ. The 292 results of the study also suggest the ICGMs can improve the EAQ process through different ways and forms of communication, regular meetings, and discussing material weakness. The professional standards and regulations in Jordan, specifically the JCGC and ISA highlighted that the importance of the role of the board of directors in the monitoring process. The findings of the research also emphasized that the Jordanian external auditors perceived existence of regular and effective communication between the external auditor and internal auditor lead to avoid any duplications and perform effective audit service in a timely manner which reflects on the quality of the monitoring process over the financial reporting as well as cooperating together to provide valuable recommendations in order to promote the internal control weakness and prevent any fraud. The findings of the research offer some implications that could help the public companies in ensuring the service that the external auditors are providing is high quality and reliable. The public companies should activate the accountability system in the companies and establish strong policy for the ICGMs to ensure that all ICGMs perform their work professionally with strong documentation and evidence to support their work.

\section{IMPLICATIONS FOR THE RESEARCHERS}

Audit and governance mechanisms research can offer theoretical perspective and framework for the corporate governance process and system particularly the role of ICGM in improving some aspects of EAQ. This study has provided 
comprehensive empirical evidence, a strong base and solid background for future researchers to build upon them. The results of this study offer inferences and implications for the scholars in the audit and governance areas. It also provided some recommendations for future research. Specifically, this study extended the EAQ research and practice through providing empirical evidence which examines the conceptualised relationship between the ICGMs and EAQ as well as how these relationships occur. A significant motivation for this study was a concern to go beyond the existing approaches to extend and advance the literature that measures the influence of the ICGMs on EAQ. More importantly, the results reveal that audit practice in Jordan is experiencing some difficulties in terms of the independence of the auditor especially, for the small local firms and providing non-audit service. In addition, there is no professional body for board of director; internal audit and audit committee like Jordanian association of certified public accountant (JACPA) for the external auditor, thus, responsibility of the bodies needs to be formally overseen by a higher authority. For the policymakers, this study offers a unique proposition to improve the effectiveness of the ICGM to achieve EAQ (Almasria, 2021).

This study established a conceptual relationship between the ICGM and EAQ, this research also contributes to the body of knowledge, in terms of audit quality literature, through improving the understanding of the meaning of EAQ and how the ICGM can improve it from the perceptions of the Jordanian external auditors (Masadeh et al., 2021). In terms of methodology, this research stems from employing the mixed methods that has not been employed previously, as this methodology and its findings provide a comprehensive picture and improve the interpretations of the relationships between these variables. The findings recommended that effective ICGM are associated with better quality of audit service. This study also demonstrated the significance of the monitoring role of these mechanisms and how they can improve the quality of the external audit process (Alawaqleh et al., 2021). The findings also highlighted the role of EAQ in reducing the agency problem through reducing information asymmetry and improving the transparency through enhancing the level of control. It also highlighted that there are various ways and channels that can be used for the interacting and communicating between the internal and external auditor. This study has pursued to move accounting argument further than the stalemate of "positivism" paradigm to "post-positivism" paradigm, it also new insights and understandings could offer from employing mixed methods which can potentially expand the knowledge and empirical evidence about this relationship. Consequently, this study has connected the theoretical gaps and empirical work. These findings can be expanded by examining other developing countries' context which has similar institutional characteristics.

\section{CONCLUSION}

The thesis examines the perceptions of the external auditors concerning how ICGM influence EAQ in Jordan. The research was motivated by several finance scandals in recent years, as well as inconclusive results in existing studies. It seeks to examine important interrelated issues, specifically to examine the effect of:

(i) the characteristics and responsibilities of the board of directors;

(ii) the responsibilities of the audit committee;

(iii) the internal audit characteristics and performance on external audit quality.

The overall aim of the thesis is to gain a better understanding of the relationship ICGM and EAQ. The study mainly based on the agency theory assumptions to develop research questions as explained earlier. The finding results of the study illustrated that one of the main responsibilities of the board is monitoring other mechanisms and ensuring effective monitoring system, which can contribute to the quality of the audit process through monitoring the audit service, non- audit service as well as the relationships between different mechanisms. The results of these stages are aligned with the prior literature that indicated the effective board of directors improves the monitoring process over the financial reporting (Abbott, 2003; O'sullivan, 2000). The quantitative data established significant association between the board of directors' responsibilities in terms of assessing the independence of the auditor from the client and EAQ process. The qualitative data emphasised on how the external auditor should perform their work independently, but the audit committee should evaluate the auditor's work and results then accordingly ask them to provide more details and evidence.

Furthermore, the findings of the interviews highlighted that it is vital for the external auditor to interact regularly with the ICGM (e.g., board of director) to discuss with them the initial results especially about any concerns that the external auditors have about specific results. Meetings allow the external auditor to communicate their findings and get feedback from the audit committee in order to be able to build the final report. They highlighted that the board of directors play a dynamic role in the external audit service through evaluating and providing feedback about the auditor findings and performance. According to the qualitative findings this could occur through meeting with the board of directors and the guidance from them. This is aligned with the regulations which stated that board of director should discuss the auditor results.

\section{REFERENCES}

Adeyemi, S. B., Okpala, O. \& Dabor, E. L. (2012). Factors affecting audit quality in Nigeria. International Journal of Business and Social Science, 3(20), 20-25.

Ahrens, T. \& Chapman, C. S. (2006). Doing qualitative field research in management accounting: Positioning data to contribute to theory. Accounting, Organizations and Society, 3( 8), 819-841.

Attride-Stirling, J. (2001). Thematic networks: An analytic tool for qualitative research. Qualitative Research, 1(3), 385-405.

Attride-Stirling, J. (2001). Thematic networks: An analytic tool for qualitative research. Qualitative Research, 1 (3), 385-405.

Antle, R. (1984). Auditor independence. Journal of Accounting Research, 120.

Arnold, B. \& De Lange, P. (2004). Enron: An examination of agency problems. Critical Perspectives on Accounting, 15(6), 751-765.

Almasria, N. (2021). Determinant Governance Mechanisms Affecting the Quality of Auditing the External Auditors' Perceptions. British Journal of Economics, Finance and Management Sciences, 18 (1), 38-66.

Alawaqleh, Q. A., \& Almasria, N. A. (2021). The Impact of Audit Committee 
Performance and Composition on Financial Reporting Quality in Jordan. International Journal of Financial Research, 12(3), 55-69.

Alawaqleh, Q. A., Almasria, N. A., \& Alsawalhah, J. M. (2021). The Effect of Board of Directors and CEO on Audit Quality: Evidence from Listed Manufacturing Firms in Jordan. The Journal of Asian Finance, Economics, Business, 8(2), 243-253.

Almasria, N., Airout, R. M., Samara, A. I., Saadat, M., \& Jrairah, T. S. (2021). The role of accounting information systems in enhancing the quality of external audit procedures. Journal of management Information and Decision Sciences, 24(7), 1-23.

Almasria, N. A. (2018). The relationship between internal corporate governance mechanisms and the quality of external audit processempirical evidence from Jordan.

Almasria, N. (2021). Determinant Governance Mechanisms Affecting the Quality of Auditing the External Auditors' Perceptions. British Journal of Economics, Finance and Management Sciences, 18(1), 38-66.

Abdulnafea, A. L., Almasria, N. A., \& Alawaqleh, Q. (2022). The effect of working capital management and credit management policy on jordanian banks'financial performance. Banks and Bank Systems, 16(4), 229-239. doi:10.21511/bbs.16(4).2021.19.

Abdulnafea, A. L., Almasria, N. A., \& Alawaqleh, Q. (2022). the effect of working capital management and credit management policy on jordanian banks'financial performance.

Beisland, L. A., Mersland, R. \& Strøm, R. Ø. (2015). Audit quality and corporate governance: Evidence from the microfinance industry. International Journal of Auditing, 19(3), 218-237.

Braun, V. \& Clarke, V. (2006). Using thematic analysis in psychology. Qualitative research in psychology, 3(2), 77-101.

Bryman, A. \& Burgess, B. (2002). Analyzing qualitative data, Routledge.

Bryman, A. (2012). 2001. Social research methods.

Boyatzis, R. E. (1998). Transforming qualitative information: Thematic analysis and code development, sage.

Ball, A., Owen, D. L. \& Gray, R. (2000). External transparency or internal capture? The role of third-party statements in adding value to corporate environmental reports1. Business strategy and the environment, 9(1), $1-23$

Beck, C. T. (1993). Qualitative research: The evaluation of its credibility, fittingness, and auditability. Western journal of nursing research, 15 (2), 263-266

Bryman, A. \& Burgess, R. G. (1994). Developments in qualitative data analysis: An introduction. Analyzing qualitative data, 1-17.

Braun, V. \& Clarke, V. (2006). Using thematic analysis in psychology. Qualitative research in psychology, 3(2), 77-101.

Bettinelli, C. (2011). Boards of director s in family firms: An exploratory study of structure and group process. Family Business Review, 24(2), 151-169.

Bathala, C. T. \& Rao, R. P. (1995). The determinants of board composition: An agency theory perspective. Managerial and decision economics, $16(1), 59-69$

Chen, Y\& Rezaee, Z. (2013). Ownership structure, financial reporting fraud and audit quality: Chinese evidence. International Journal of Accounting, Auditing and Performance Evaluation, 9(1), 75-99.

Creswell, J. W. (2013). Research design: Qualitative, quantitative, and mixed methods approaches, Sage publications.

Creswell, J. W. (2013). Research design: Qualitative, quantitative, and mixed methods approaches, Sage publications.

Creswell, J. W., Plano Clark, V. L., Gutmann, M. L. \& Hanson, W. E. (2003). Advanced mixed methods research designs. Handbook of mixed methods in social and behavioral research, pp. 209-240

Donaldson, L. (1990). The ethereal hand: Organizational economics and management theory. Academy of management review, 15(3), 369-381.

Deangelo, L. E. (1981). Auditor size and audit quality. Journal of accounting and economics, 3(3), 183-199.

Deangelo, L. E. (1981). Auditor size and audit quality. Journal of accounting and economics, 3(3), 183-199.

Felix Jr, W. L. \& Gramling, A. A. (2001). The contribution of internal audit as a determinant of external audit fees and factors influencing this contribution. Journal of Accounting Research, 39(3), 513-534.

Fan, J. P. \& Wong, T. J. (2005). Do external auditors perform a corporate governance role in emerging markets? Evidence from east asia. Journal of Accounting Research, 43(1), 35-72.

Fan, J. P. \& Wong, T. J. (2005). Do external auditors perform a corporate governance role in emerging markets? Evidence from east asia. Journal of Accounting Research, 43(1), 35-72.

Fylan, F. (2005). Semi structured interviewing. A handbook of research methods for clinical and health psychology, 65-78.

Florackis, C. (2008). Agency costs and corporate governance mechanisms: Evidence for uk firms. International Journal of Managerial Finance, 4 (1), 37-59.

Frost, N. (2011). Qualitative research methods in psychology: Combining core approaches, McGraw-Hill Education (UK).

Gronroos, C. (1988). Service quality: The six criteria of good perceived service. Review of business, 9(3), 10.

Golafshani, N. (2003). Understanding reliability and validity in qualitative research. The qualitative report, 8(4), 597-606

Golafshani, N. (2003). Understanding reliability and validity in qualitative research. The qualitative report, 8(4), 597-606.

Holm, C. \& Laursen, P. B. (2007). Risk and control developments in corporate governance: Changing the role of the external auditor? Corporate Governance: An International Review, 15(2), 322-333.

Hsu, H.-H. \& Wu, C. Y.-H. (2014). Board composition, grey directors and corporate failure in the uk. The British Accounting Review, 46(3), 215227.

Hussainey, K. (2009). The impact of audit quality on earnings predictability. Managerial Auditing Journal, 2(4), 340-351.

Halbouni, S. S. (2015). The role of auditors in preventing, detecting, and reporting fraud: The case of the united arab emirates (uae) International Journal of Auditing, 19(2), 117-130.

Halbouni, S. S. (2015). The role of auditors in preventing, detecting, and reporting fraud: The case of the united arab emirates (uae) International Journal of Auditing, 19(2), 117-130.

Hussainey, K. (2009). The impact of audit quality on earnings predictability. Managerial Auditing Journal, 24(4), 340-351.

Ivankova, N. V., Creswell, J. W. \& Stick, S. L. (2006). Using mixed-methods sequential explanatory design: From theory to practice. Field methods 18(1), 3-20.

Jensen, M. C. \& Meckling, W. H. (1976). Theory of the firm: Managerial behavior, agency costs and ownership structure. Journal of financial economics,.3(4), 305- 360

Jensen, M. C. \& Meckling, W. H. (1976). Theory of the firm: Managerial behavior, agency costs and ownership structure. Journal of financial economics, 3(4), 305- 360

Kane, G. D. \& Velury, U. (2004). The role of institutional ownership in the market for auditing services: An empirical investigation. Journal of Business Research, 57(9), 976-983.

Kikhia, H. Y. (2014). Board characteristics, audit committee characteristics, and audit fees: Evidence from jordan. International Business Research $7(12)$

Karaibrahimoglu, Y. Z. (2013). Is corporate governance a determinant of auditor choice? - evidence from turkey/kurumsal yönetim denetçi seçiminde belirleyici midir?-türkiye'den bulgular. Ege Akademik Bakis, 13(2), 273.

Karalbrahİmoğlu, Y. Z. (2013). Is corporate governance a determinant of auditor choice? - evidence from turkey. Ege Academic Review, 13(2).

Lin, Z. J. \& Liu, M. (2009). The impact of corporate governance on auditor choice: Evidence from china. Journal of International Accounting, Auditing and Taxation, 18(1), 44-59.

Lin, Z. J. \& Liu, M. (2009). The determinants of auditor switching from the perspective of corporate governance in china. Corporate Governance: An International Review, 17(4), 476-491.

Lawrence, A., Minutti-Meza, M. \& Zhang, P. (2011). Can big 4 versus nonbig 4 differences in audit-quality proxies be attributed to client characteristics? The Accounting Review, 86(1), 259-286.

Lewis, J. \& Ritchie, J. (2003). Generalising from qualitative research. Qualitative research practice: A guide for social science students and researchers, 2, 347-362.

Lewis, J. \& Ritchie, J. (2003). Generalising from qualitative research. Qualitative research practice: A guide for social science students and researchers, 2, 347-362.

Makni, I., Kolsi, M. C. \& Affes, H. (2012). The impact of corporate governance mechanisms on audit quality: Evidence from tunisia. IUP Journal of Corporate Governance, 11(3), 48

Mahdavi, G., Monfared Maharlouie, M., Ebrahimi, F. \& Sarikhani, M. (2011). The impact of corporate governance on auditor choice. International Research Journal of Finance and Economics, no.68.

Masadeh, A. A., Saadat, M., Almasria, N. A., Jrairah, T. S., \& Alsawalhah, J. M. (2021). investigating the role of applying the quality cost approach in the manufacturing system in the public shareholding manufacturing company in jordan. Academy of accounting and financial Studies Journal, 25(5), 1-14.

O'sullivan, N. (2000). The impact of board composition and ownership on audit quality: Evidence from large uk companies. The British Accounting Review, 32(4), 397-414.

O'sullivan, N. (2000). The impact of board composition and ownership on audit quality: Evidence from large uk companies. The British Accounting Review, 32(4), 397-414.

Palmrose, Z.-V. (1988). 1987 competitive manuscript co-winner: An analysis of auditor litigation and audit service quality. Accounting Review, 55-73.

Rasmussen, L. B., Vargo, L. E., Reavey, D. A. \& Hunter, K. S. (2005) 
Qualitative data and the credibility criteria. Advances in Neonatal Care, 1, (5), pp. 28-38.

Ritchie, J., Lewis, J., Nicholls, C. M. \& Ormston, R. (2013). Qualitative research practice: A guide for social science students and researchers, Sage.

Remmers, H., Shock, N. \& Kelly, E. (1927). An empirical study of the validity of the spearman-brown formula as applied to the purdue rating scale. Journal of Educational Psychology, 18(3,) pp. 187.

Roulston, K. (2010). Considering quality in qualitative interviewing. Qualitative Research, 10(2), pp.199-228.

Soliman, M. \& Elsalam, M. A. (2013). Corporate governance practices and audit quality: An empirical study of the listed companies in Egypt. Available at SSRN 2257815.

Soliman, M. \& Elsalam, M. A. (2013). Corporate governance practices and audit quality: An empirical study of the listed companies in Egypt. Available at SSRN 2257815.

Silverman, D. (2001). Interpreting qualitative data: Methods for interpreting talk, text and interaction. London: Sage.

Spencer, L., Ritchie, J., Lewis, J. \& Dillon, L. (2003). Quality in qualitative evaluation: A framework for assessing research evidence.

Srivastava, A. \& Thomson, S. B. (2009). Framework analysis: A qualitative methodology for applied policy research.

Silverman, D. (2000). Analyzing talk and text. Handbook of qualitative research2(0), pp. 821-834.

Turnbull, S. (1997). Corporate governance: Its scope, concerns and theories. Corporate Governance: An International Review, 5(4), pp. 180-205.

Teddlie, C. \& Tashakkori, A. (2003). Major issues and controveries inthe use of mixed methods in the social and behvioral sciences. Handbook of mixed methods in social \& behavioral research, pp. 3-50.

Voeller, D., Bremert, M. \& Zein, N. (2013). Interdependencies between auditing and corporate governance-evidence from germany. Schmalenbach Business Review, 65, pp. 198-226.

Vaivio, J. (2008). Qualitative management accounting research: Rationale, pitfalls and potential. Qualitative Research in Accounting \& Management, 5(1), pp. 64-86.

Zanani, W., Abdullah, W., Shahnaz, I. \& Nurasyikin, J. (2008). The impact of board composition, ownership and ceo duality on audit quality: The malaysian evidence.

Zanani, W., Abdullah, W., Shahnaz, I. \& Nurasyikin, J. (2008). The impact of board composition, ownership and ceo duality on audit quality: The malaysian evidence.

Zanani, W., Abdullah, W., Shahnaz, I. \& Nurasyikin, J. (2008). The impact of board composition, ownership and ceo duality on audit quality: The Malaysian evidence.

Zahra, S. A. \& Pearce, J. A. (1989). Boards of directors and corporate financial performance: A review and integrative model. Journal of management, 15(2), pp. 291-334.

Zanani, W., Abdullah, W., Shahnaz, I. \& Nurasyikin, J. (2008). The impact of board composition, ownership and ceo duality on audit quality: The Malaysian evidence.

Zureigat, Q. M. (2011). The effect of ownership structure on audit quality: Evidence from Jordan. International Journal of Business and Social Science, 2(10), pp. 38-46. 